\title{
Second language acquisition and first language loss in adult early bilinguals: exploring some differences and similarities
}

Silvina Montrul University of Illinois at Urbana-Champaign

This study compares the linguistic knowledge of adult second language (L2) learners, who learned the L2 after puberty, with the potentially 'eroded' first language (L1) grammars of adult early bilinguals who were exposed to the target language since birth and learned the other language simultaneously, or early in childhood (before age 5). I make two main claims: (1) that the L1 grammar of bilinguals at a given stabilized state (probably endstate) resembles the incomplete (either developing or stabilized) grammars typical of intermediate and advanced stages in L2 acquisition; and (2) that despite similar patterns of performance, when language proficiency is factored in, early bilinguals are better than the L2 learners, probably due to exposure to primary linguistic input early in childhood.

I offer empirical evidence from an experimental study testing knowledge of the syntax and semantics of unaccusativity in Spanish, conducted with English-speaking L2 learners and Englishdominant Spanish heritage speakers living in the USA. I consider recent treatments of unaccusativity and language attrition within the generative framework (Sorace, 1999; 2000a; 2000b), that offer a unifying account of the formal parallels observed between these two populations I discuss how input, use and age may explain differences and similarities in the linguistic attainment of the two groups. 


\section{Introduction}

First language (L1) loss is:

the temporary or permanent loss of language ability as a reflected in a speaker's performance or in his/her ability to make grammaticality judgments that would be consistent with native speaker monolinguals at the same age and stage of language development. (Seliger, 1996: 606)

Language loss covers a variety of linguistic phenomena: it can be the result of brain damage (aphasia) and senile dementia, or can be nonpathological and develop as a result of an extensive and intensive period of language contact, as in a bilingual situation (e.g., bilingual societies, immigrant and indigenous communities). This article is concerned with characterizing structural, linguistic aspects of L1 loss in the context of bilingualism, particularly incomplete or interrupted acquisition (Polinsky, 1997; 2000; in press; Montrul, 2002), as I define below, and with drawing some parallels and differences with adult second language acquisition (SLA).

Efforts to document and explain external influences on the language loss phenomenon have been most prominent in the sociolinguistic tradition (Dorian, 1973; 1978; 1981; Gal, 1979; Elías Olivares, 1983; Ocampo, 1990; Silva-Corvalán, 1994; Lipski, 1993; Zentella, 1997; and some contributions in Seliger and Vago, 1991). On a different front, a tradition of experimental psycholinguistic research has investigated how bilinguals of different proficiency levels in the two languages access or retrieve lexical items, or process sentences on-line, and how the two linguistic systems prime or inhibit each other (Grosjean and Soares, 1986; Grosjean, 1994; de Groot, 1995; de Groot and Kroll, 1997; Nicol, 2001, Dussias, 2003; among others). With the exception of work by Seliger (1991; 1996), Sharwood Smith and van Buren (1991), Platzack (1996), Polinsky (1997), Sorace (2000a), Toribio (2001), Gürel (2002) and Montrul (2002), much remains to be done to understand the formal and linguistic nature of the attrition process in a bilingual context and how it affects the human language faculty. One major reason why this area of research has remained relatively underexplored until now is perhaps the lack of theoretical and methodological tools to investigate the phenomenon (for discussion, see Sharwood Smith and van Buren, 1991). 
Early research on this type of nonpathological attrition attempted to draw inverse parallels with L1 acquisition. An example of this is Jakobson's (1941) influential regression hypothesis, which states that language loss is a mirror image of language acquisition. Although this hypothesis was originally proposed to trace parallels between language attrition as a result of aphasia and normal L1 acquisition by children, it has driven much research in language loss under normal circumstances (see for example, de Bot and Clyne, 1989; Jordens et al., 1989; Hyltenstam and Viberg, 1993;). However, the results of these different studies do not offer categorical support for the hypothesis. As de Bot and Clyne (1989) and de Bot and Weltens (1991) pointed out, the regression hypothesis is untenable for understanding language loss in a bilingual setting because language acquisition implies developmental stages and gradualness, whereas pathological language loss tends to be abrupt and affects localized areas of the brain and linguistic abilities. Beyond the regression hypothesis, Pan and Berko Gleason (1986) also proposed that normal and uninterrupted L1 acquisition provides a good baseline to investigate language loss. Indeed, the field of L1 acquisition has had much to offer other sister fields in terms of theoretical models and research methods. For example, much contemporary research characterizing the linguistic nature of second language acquisition grew out of seeking to understand differences and similarities between adults learning a second language (L2) and children learning their L1 (for recent overviews, see Bley-Vroman, 1990; Meisel, 1997; Herschensohn, 2000; Hawkins, 2001; White, 2003).

In this article, I argue that in order to better understand the relationship between language acquisition in general and language loss in the context of bilingualism, it makes more sense to look at L2 acquisition rather than at L1 acquisition, particularly because there are more factors in common between L2 acquisition and L1 loss in bilinguals. In many respects, L1 loss in a bilingual context is the flip side of the L2 acquisition coin. In the language loss situation, there is the potential effect of another language (an L2) on the L1 (for a recent comprehensive overview of this phenomenon, see Pavlenko, 2000; Cook, 2003). In addition, there is the potential effect of developmental processes resulting from the operation of universal linguistic mechanisms that are 
typical of language development (due to change or acquisition) and that cannot be traced back to the effects of another language. Furthermore, incompleteness with respect to the grammar of monolingual native speakers results from the effects of reduced or interrupted input and exposure to the L1, as well as to reduced frequency and degree of use of the L1 (Köpke, 2002). Because the influence of a previously acquired linguistic system, developmental errors arising from language universals, amount and quality of input, and frequency of use all play important roles in the acquisition of a second language, there may be similarities worth exploring between L2 acquisition and L1 loss in a bilingual setting. If some of these factors contribute to the phenomenon of fossilization in L2 acquisition, they may also contribute to language arrest, and even 'indeterminate' grammars (Sorace, 1993) in bilinguals. At the same time, early bilinguals and L2 learners differ in their ethnic background and linguistic past, particularly age of onset of bilingualism and nature and timing of input.

Because the L2 acquisition field has grown tremendously in the past two decades, both in terms of theoretical rigour and methodological sophistication, the time has also come for this field to contribute to its sister field of bilingualism. In fact, the close relationship between SLA and L1 loss has been implicit and explicit in a number of very recent studies stressing the finding that in many grammatical areas, bilinguals and L2 learners have been shown to end up with very similar grammars (Lynch, 1999; Sorace, 1999; 2000a; Gürel, 2002; Jordens, 2002; Montrul, 2002; 2004a). Finally, by applying to the language loss situation empirical methods that have already been successfully employed to assess linguistic knowledge in second language learners, we can draw interesting comparisons and explore some revealing differences and similarities between the two populations.

A study of this sort also has important practical implications. In many institutions in the USA, traditional foreign language classes have had to open the doors to second and third generation bilinguals who have some degree of oral proficiency but who may be illiterate in the heritage language. Unfortunately, the specific linguistic and pedagogical needs of this population are still very poorly understood. Therefore, comparing typical adult second language acquisition with bilingual speakers of a heritage language will enable us to understand the 
possibilities and limits of childhood and post-puberty bilingualism, which may in turn have consequences for educational policy and instructional interventions.

\section{Defining the populations}

Before proceeding with the rest of the discussion, I would like to clarify the particular case of L1 loss I will be referring to in this article: the case of heritage speakers living in the USA. While the term 'second language learner' typically refers to a sequential bilingual or an adult who learned an L2 after puberty, the term 'heritage speaker' is used here to refer to an adult simultaneous bilingual and a child L2 learner 'raised in a home where a non-English language is spoken, who speaks or merely understands the heritage language, and who is to some degree bilingual in English and the heritage language' (Valdés, 2000: 1).

The term 'language loss' is a general term used to refer both to L1 attrition and incomplete acquisition, a distinction that has also been made by Polinsky (1997; 2000; in press). In a strict sense, L1 attrition is understood as loss of linguistic ability after an L1 was acquired. This assumes that a linguistic system was acquired completely, and remained stable for a while before loss of some sort occurred. This is the case of adult first generation immigrants who learned the L2 as adults (after the end of the critical period) and are living in the L2 environment, as those studied by Major (1992), Sorace (1999; 2000a), Gürel (2002), Köpke (2002) and Schmid (2002), among others. They are 'forgetters' (who forgot aspects of their L1) in Polinsky's (1997) distinction.

Incomplete or interrupted acquisition, on the other hand, is used to refer to the case of bilinguals who never fully acquired one of the languages they were exposed to as children. That is, these are either simultaneous bilinguals or early child L2 learners who were exposed to the second or majority language early in childhood, perhaps in the pre-school or early school years (but crucially well before the end of the critical period), and this language later become primary or dominant. Input and use in what used to be the primary language was either interrupted or significantly reduced. The typical cases are second and third generation immigrants, and the majority of heritage speakers in the USA would fall into this category. Although Polinsky (1997) refers to 
these bilinguals as incomplete learners, I believe that in fact it is not clear whether these are cases of incomplete acquisition or first language attrition. When we look at these bilinguals as adults, it is difficult, if not impossible, to reconstruct the specific ways in which the proficiency in their L1 was affected just by relying on personal reports about degree and frequency of language use. We know that bilingual school-aged children are very vulnerable to abrupt shifts in language dominance (Vihman and McLaughlin, 1982; Kohnert et al., 1999). In cases when shift leads to loss, it is possible that these adults had more knowledge of their family language at some point during their early childhood, and then lost parts of it, stabilizing at a particular incomplete state (for a study of child simultaneous bilinguals' erosion of verbal morphology in Spanish, see Silva-Corvalán, 2003). Nevertheless, for ease of exposition, I refer to these as cases of incomplete acquisition.

Because many of these individuals did not receive schooling in their heritage language, as adults they typically display significant differences from monolingual native speakers who speak the full variety, and are significantly more fluent and linguistically more advanced and sophisticated in their primary (L2) language than in the heritage language (Polinsky, 2000). Indeed, a well-documented fact about this particular population is that the range of proficiency in the heritage language varies considerably: while some have limited productive ability and produce errors similar to those of adult L2 learners and child L1 learners; others are as proficient as native speakers in familiar and academic settings, in production and comprehension, as well as in written and spoken language (Lipski, 1993; Valdés, 2000).

Based on the above observations about these bilinguals, my goals in this article are twofold:

- to begin to understand the degree and patterns of grammatical variation in proficiency levels in L2 learners and early bilinguals in the secondary language (Spanish) by focusing on an area of grammar known to be vulnerable in second language acquisition; and

- by focusing on unaccusativity - a universal semantic-syntactic distinction between two classes of intransitive verbs - a second goal is to explore whether syntax and semantics can be differentially affected in these two populations at a given stage. 
Let us start by presenting in the next section the linguistic phenomenon under consideration.

\section{Unaccusativity}

Unaccusativity is a phenomenon that has received considerable attention in linguistic theory and in formal approaches to L2 acquisition. Unaccusativity refers to the classification of intransitive verbs into unaccusatives and unergatives based on the lexico-semantic properties of the event and the agentive or non-agentive nature of the single participant in the event. Thus, unergative verbs like talk or work denote a process and have agentive subjects, while unaccusative verbs like fall or disappear refer to instantaneous, point-like events or change of states and have non-agentive subjects. A point of debate among linguists of different theoretical approaches is whether the difference between these two classes is purely semantic, purely syntactic, or results from interplay of these two domains.

According to the Unaccusative Hypothesis (Perlmutter, 1978; Rosen, 1984; Burzio, 1986), however, the distinction between the two classes in mainly syntactic. ${ }^{1}$ Unergative verbs are syntactically characterized by having an external argument (the agent occupies the subject position) and no internal argument, as in (1b), while unaccusative verbs have no external argument, and the patient is base-generated in object position, as an internal argument, as in (2b), like the object of transitive verbs. The patient then moves to subject position to check nominative case, leaving a trace behind (2c). Thus, unaccusative and unergative verbs are structurally different, but not on the surface level.

1) a. John walked. unergative

b. [John [

2) a. John arrived. unaccusative

b. [e [vP arrived John]]

c. [John [ ${ }_{\mathrm{VP}}$ arrived $\left.t_{\mathrm{i}}\right]$ ]

${ }^{1}$ Rosen (1984) notes that many verbs that have the same syntax are nevertheless classified as unaccusative or unergative. For example, the verbs shudder and shake in English have basically the same meaning, but while shudder in unergative, shake is unaccusative and alternates in transitivity. The specific classification of lexical items as one type or the other is also not consistent, such that in Italian the equivalent of to die is unaccusative but in Choctaw it is unergative. 
Notably, the differences between these two classes of intransitive verbs appear to be universal (all languages have it), and may have language-specific syntactic and morphological consequences of the distinction, depending on the language. For example, in English, certain unaccusative verbs can appear with existential subjects (There appeared three men) and in the resultative construction (The bag fell open), while unergative verbs cannot (*There worked three men, *Mary laughed hoarse) (Perlmutter, 1978; Levin and Rappaport Hovav, 1995). In Italian, Dutch and French, unaccusative verbs take the perfective auxiliary essere, zijn, être 'to be' (The man is gone), while unergative and transitive verbs take the auxiliary avere, hebbe, avoir 'to have' (The children have laughed) (Burzio, 1986; Legendre, 1989; Van Valin, 1990; Sorace, 1993a; van Hout et al., 1992; Zaenen, 1993). And in Japanese, the adverb takusan 'a lot' has two distinct readings depending on the verb: with unaccusative verbs the adverb quantifies the argument of the verb (Many books fell), whereas with unergative verbs the adverb quantifies the activity described by the verb and not the argument. (The children laughed a lot, and not*Many children laughed) (Kageyama, 1996).

If the distinction between unaccusative and unergative verbs is purely structural, then we expect all unaccusative and unergative verbs to behave alike syntactically. However, Sorace (2000b) has recently uncovered that while many verbs within each class display consistent syntactic unaccusative or unergative behaviour across and within languages, others display variable syntactic behaviour, depending on the contribution of other aspectual or thematic elements in the sentences in which they appear. For example, change of state verbs (like decay), agentive verbs of directed motion (like run, march) and verbs of existence (like exist, etc.) systematically display variable syntactic behaviour with auxiliary selection, and are sensitive to other aspectual and thematic elements in the sentence. For example, the verb run in Italian, and in many other languages, selects the perfect auxiliary 'to have', displaying unergative behaviour when it is atelic (Maria ha corso velocemente 'Mary has run fast'), but it selects 'to be' and displays unaccusative behaviour when a goal prepositional phrase is added, making the event telic: Maria é corso in farmacia 'Mary ran to the pharmacy'.

By contrast, talk and sing always select the perfect auxiliary 'to have' in languages that have the auxiliary distinction, and the 
telicization of the predicate with another element in the sentence does not select 'to be' (I colleghi hanno chiaccherato tutto il pomeriggio 'My colleagues chatted the whole afternoon'). Similarly, the unaccusatives come and arrive always select 'to be' as auxiliary, and agentivity or detelicization of the event does not affect the choice of auxiliary ( $\underline{\text { Sono }}$ arrivati ospiti per ore e ore 'Guests arrived for hours'). Based on facts such as these, Sorace (2000b) proposed that there is a continuum (what she calls 'hierarchy') of gradients of unaccusative/unergative verbs of potential universal significance, as in (3). This hierarchy is related to the semantic concepts of telicity and agentivity. The extremes of the continuum (what she calls 'core') are the prototypical unaccusative and unergative verbs. The verbs in the middle are more or less unaccusatives or unergatives ('less core' or 'peripheral'), depending on their position in the continuum with respect to the extremes.

3) Sorace's (2000b) Unaccusativity Hierarchy:

change of location
[directed motion]
change of state
uncontrolled process
$\begin{aligned} & \text { continuation of a pre-existing state } \\ & \text { existence of state } \\ & \text { uncontrolled process } \\ & \text { [emission] } \\ & \text { [involuntary reaction] } \\ & \text { controlled processes (motional) } \\ & \text { controlled process (nonmotional) }\end{aligned}$

For most linguists and psycholinguists, the acquistion of unaccusativity represents a classic 'poverty of the stimulus' problem. ${ }^{2}$ At the surface, all intransitive verbs look alike: they have one argument. However, it is clear that they do not behave alike syntactically. How does the learner find out, just from experience, which particular verbs belong to which class and the reason for the classification? In some languages, children hear unaccusative and unergative verbs with different auxiliaries, but in languages that do not have the auxiliary distinction, 
like English or Spanish, they don't. A similar problem occurs in L2 acquisition, since the unaccusative/unergative distinction is never taught in language classrooms and is underrepresented in language teaching materials (for an analysis of frequency of verb classes in ESL materials, see Juffs, 1998). Although aspects of lexical-semantics may be transferred from the L1 to the L2 (White, 1991; Inagaki, 2002), it is also not clear to what extent the native language plays a role with the acquisition of the syntax of these verbs. Therefore, unaccusativity is an ideal testing ground to investigate very intuitive, subtle and sophisticated aspects of linguistic knowledge, since not everything there is to know about these verbs is available from direct experience, explicit instruction and/or metalinguistic awareness.

According to van Hout (1996), children already come equipped with knowledge of the unaccusative/unergative syntactic distinction but must learn the semantic classification by distributional evidence. In general, very few errors have been documented in the L1 acquisition of unaccusativity (Borer and Wexler, 1987; van Hout et al. 1992; Snyder et al. 1995). By contrast, a number of SLA studies have reported that unaccusative verbs, but not unergatives, cause persistent problems to L2 learners of English of various L1 backgrounds, especially at high intermediate and quite advanced levels of interlanguage development (e.g., Kellerman, 1978; Zobl, 1989; Hirakawa, 1995; Yip, 1995; Balcom, 1997; Oshita, 2001; Sorace and Shomura, 2001). Comparable difficulties with unaccusatives have been found in other L2 languages, such as Italian (Sorace, 1993a), French (Sorace, 1993b), Japanese (Hirakawa, 2000; 2001) and Chinese (Yuan, 1999). Typical errors in English are:

- production (in written and oral texts) and acceptance in judgement tasks of passive unaccusatives: *An accident was happended;

- incorrect rejection of unaccusative verbs in grammatical NP-V sentences (John left) in judgement tasks, but correct use of this sentence pattern in all other cases;

- production and acceptance in experimental tasks of causative errors with unaccusative and unergative verbs $(*$ The man disappeared the ball), but errors with unergatives are 'unlearned' earlier than those with unaccusatives. 
To explain these errors, Oshita (2001) proposed the Unaccusative Trap Hypothesis. According to this hypothesis, L2 learners initially assume that all intransitive verbs are unergatives, with an underlying subject. As a result of this misguided assumption, L2 learners adopt a linking rule - the single argument linking rule - that is insensitive to semantic notions, and only refers to the number of arguments. According to Oshita, such misanalysis explains why at early and intermediate levels of proficiency learners accurately produce the two classes of intransitive verbs with preverbal subjects, and passivization errors are observed. At more advanced levels of proficiency, L2 learners discover that there are two classes of intransitive verbs, and they 'restructure' their interlanguage grammars accordingly. Presumably, they have now discovered the semantic notions that determine which argument gets mapped to which position in the syntax. Therefore, at this point, learners posit two different lexico-semantic and syntactic representations: one for unaccusatives and one for unergatives. Interestingly, during this restructuring period, when learners now reanalysed the argument of unaccusatives as objects and the arguments of unergatives as subjects, learners continue to be very accurate with unergative verbs, but at the same time all the nontarget phenomena with unaccusative verbs appear (e.g., passive unaccusatives, reluctance to accept preverbal subjects, etc.). Eventually, L2 learners may or may not recover from these errors, depending on the structural properties of the target language and on how clear and obvious the syntactic and morphological reflexes of unaccusativity may be in that language.

Oshita's hypothesis does not take into account the behaviour of unaccusative verbs depending on a finer semantic analysis. Sorace (2000b), however, who also extensively investigated the L2 acquisition of unaccusativity in Italian, French and Japanese, noted that the potential reality of the unaccusative hierarchy she proposed finds confirmation in psycholinguistic studies. Findings from L1 acquisition have shown that while auxiliary selection with unaccusative and unergative verbs is learned quite early, it is learned even earlier with verbs displaying stable behaviour that with those that shift from unaccusative to unergative. Furthermore, experimental studies with native and L2 speakers of Italian have shown that native speakers have very strong intuitions with auxiliary selection with the 'stable' verbs and less determinate 
intuitions about syntactic behaviour with the others, attesting to these gradients of unaccusativity (Sorace, 1993a; Bard et al. 1996). Sorace (1993a) noted that even though Italian near-native speakers made fewer errors with the syntax of auxiliary selection with unaccusative and unergative verbs than beginner and intermediate learners, their judgements with some unaccusative verbs were still more indeterminate that those of the Italian native speakers. Thus, according to Sorace, near-native speakers do fully acquire the same mental representation as native speakers in this linguistic domain, especially with the semantic features of lexical items. ${ }^{3}$

To summarize thus far, the unaccusative/unergative distinction is a universal phenomenon, but languages implement different syntactic and morphological reflexes of unaccusativity. Debate exists as whether the distinction should be better characterized as a purely semantic phenomenon (Van Valin, 1990; Dowty, 1991), purely syntactic (Rosen, 1984; Burzio, 1986) or both (Levin and Rappaport Hovav, 1995). While the variable syntactic behaviour of these verbs indicates that there is a strong correlation between semantic notions and unaccusativity, it is still far from clear why particular semantic components are sensitive to certain syntactic reflexes while others are not, or why languages are sensitive to different semantic notions for the classification of intransitive verbs. ${ }^{4}$ Moreover, the syntactic distinction between the two classes of verbs cannot be denied either. An accurate explanation of the phenomena will certainly necessitate a better understanding of the interplay

\footnotetext{
${ }^{3}$ An anonymous reviewer questions why inconsistent auxiliary selection with some verbs in Italian would indicate learnability problems with the semantics of unaccusative verbs rather than the syntax. The problem is that the unstable verbs are precisely those that can shift aspectual characteristics, from telic to nontelic, across and within languages. Telicity, is a semantic notion that has syntactic correlates depending on the language. Thus, in Italian, auxiliary selection and telicity are also related. A good testing case is perhaps a language like Spanish (or Japanese, as discussed by Sorace and Shomura 2001), where there is no auxiliary to be chosen because there is only one, so syntax could not always give clues about ambiguity with some verbs in this language. Therefore, learners have to rely more on the semantics of the verbs. It is possible that if learners fail to achieve nativelike representations with features of lexical items it is because the input they received for those items is syntactically or morphologically ambiguous (depending on the language).

${ }^{4}$ That is, whereas the aspectual notion of 'telicity' (or 'change with an endpoint') is syntactically relevant for the classification of unaccusative verbs in Dutch (so that if the argument of an intransitive verb denotes an entity undergoing a telic change, the argument is mapped to object position), German relies on the semantic concept of 'transition' (Seibert, 1993, cited in Sorace, 1995), Italian on 'existence of a state' (Sorace, 1995), and English on 'change of condition' (Sorace, 1995).
} 
between lexical and structural meaning (Rappaport Hovav and Levin, 1998; Ritter and Rosen, 1998; Sorace, 2000b; Levin and Rapport Hovav, 2002). For the present study, I assume that there is both a syntactic and a semantic dimension to the phenomenon.

\section{Research questions}

Given these facts about L2 acquisition, if errors with unaccusatives are common at intermediate and advanced levels of L2 proficiency, a question that arises is what happens with adult simultaneous bilinguals, especially those who appear to be less proficient in one of the languages. In this population, the lexicon and inflectional morphology appear to be the areas most vulnerable to incompleteness or erosion. A recent study by Köpke (2002) on attrition in German-French and German-English bilinguals revealed that lexical errors (retrieval, substitutions, borrowing, etc.) were more pronounced than morphosyntactic errors (word order, case, etc.). Just like most studies of the bilingual lexicon, Köpke's study focused on psycholinguistic approaches to the issue of access, lexical retrieval and conceptual representations during production (for a recent overview, see Kroll and Sunderman, 2003), aspects that fall within processing models of the bilingual lexicon. In this study, however, I am interested in the issue of linguistic representations. Therefore, it is open question how lexical semantics, or the links between the meaning of words and syntax, are represented or affected in unbalanced bilinguals.

Most recently, empirical work within discourse-functional (Silva Corvalán, 1994) and generative perspectives (Sorace, 2000a; Bouba et al., 2002 Montrul, 2002;) has also demonstrated that while syntax proper is impervious to language loss or attrition, syntax-related interfaces like syntax-semantics, lexical-semantics, and discoursepragmatics are not. These findings are also predictable from Sorace's (2000a) account of attrition within generative grammar under Chomsky (1995). Sorace's model relies on the distinction between interpretable and non-interpretable features of functional categories and lexical items. Interpretable features (tense, aspect, mood, focus, presupposition) contribute to meaning and are checked at the syntax-semantics and syntax-pragmatics interfaces, whereas uninterpretable features 
have purely formal, syntactic content (e.g., case, person and number agreement) and are checked at the level of the syntactic computational system. Assuming this principled distinction between the two types of formal features and the different interface levels, Sorace (2000a) proposed that language attrition affects interpretable features, rather than uninterpretable features (see also Tsimpli, 2001). Consequently, attrition is restricted to the interface between semantics and discourse/ pragmatics, and does not seem to affect the computational system, or syntax proper.

Since the phenomenon of unaccusativity has a syntactic and a semantic component, it represents an ideal testing ground to measure the differential effects of attrition or incomplete acquisition on these two domains. Moreover, as I have already discussed, unaccusativity has been extensively investigated in L2 acquisition as an example of a universal distinction underrepresented in the input (naturalistic or instructed). This study, therefore, investigates whether adult English-speaking L2 learners of Spanish discriminate syntactically between unaccusative and unergative verbs, and whether the semantic hierarchy proposed by Sorace plays a role in the acquisition of the distinction. Secondly, this study asks whether knowledge of the semantics and syntax of unaccusativity is affected in the Spanish of Spanish-English bilinguals who were exposed to the two languages since birth but who feel more competent in English, the majority language. While in Montrul (2002; 2004a) I argued that L2 learners and heritage speakers often converge on the type of linguistic knowledge attained, in this study I also focus on these similarities but further consider whether there are important differences between these two populations when proficiency levels are factored in. Before going into the specific details of the experiment, let us present how unaccusativity is manifested in Spanish.

\section{Syntactic tests for unaccusativity in Spanish}

Unlike Italian and French, Spanish no longer has two perfect auxiliaries to distinguish between the two classes of intransitive verbs: it only has haber 'to have'. However, other syntactic and morphological tests of unaccusativity in Spanish have been identified in the literature. One such test is the distribution of bare plurals (noun phrases without 
determiners) (Demonte, 1985; Torrego, 1989). As the examples in (4) and (5) show, transitive and unaccusative verbs allow bare plurals in postverbal position, while as seen in (6), unergatives do not (examples from Torrego, 1989: 254): 5
4) Han leído libros.
transitive verb
have read books
'They have read books.'
5) Han pasado camiones. unaccusative verb have passed trucks 'Trucks have passed by.'
6) "Han dormido animales. unergative verb have slept animals 'Animals have slept.'

A second syntactic test discriminating between unaccusative and unergative verbs in Spanish is the absolutive construction (de Miguel, 1992). Absolutive constructions are clauses with a past participle that modify a postposed noun phrase, and agree with it in number and gender. Absolutive constructions are grammatical with transitive (7) or unaccusative participles (8), that is, with structures that have an object, but are clearly ungrammatical if the participle is an unergative verb, as in (9), which presumably does not have an object.

7) Vendida la casa, abandonamos para siempre el valle. transitive verb sold the house abandoned forever the valley

'Once the house was sold, we left the valley for good.'

8) Muerto el perro, se acabó la rabia.

unaccusative verb dead the dog stopped the rabies

'Once the dog was dead, the rabies stopped.'

9) Nadado Juan, se sintió mejor. unergative verb swam Juan himself felt better 'Once Juan swam he felt much better.'

Furthermore, de Miguel notes that among unaccusative verbs, the participial absolutive construction is sensitive to the aspectual notion of telicity (the potential to have an endpoint). That is, this construction is grammatical with telic unaccusative verbs (those that have an

\footnotetext{
${ }^{5}$ Aranovich (2000) and other linguists have questioned the validity of this test because it appears that unergative verbs are ungrammatical with bare plural subjects only when the sentence has a presentational reading. Unergatives with bare plural subjects are grammatical in the locative inversion construction, that is, when there is a preposed locative phrase, as in Aqui han dormido animales 'Here have slept animals'. They are also acceptable when the postverbal subject is the focus of contrast, as in Han dormido animales, no hombres 'Have slept animals, not men'.
} 
endpoint), as shown in (8), but ungrammatical with atelic unaccusative verbs, such as verbs of existence, durative verbs and iterative verbs (i.e., some stative and achievement verbs in Vendler's 1967 classification). as in (10) and (11).

10) *Faltado el café, no podremos desayunar. lacked the coffee we will not be able to have breakfast 'Without any coffee left, we won't be able to have breakfast.'

11) *Ida la tormenta, podremos ir a la playa. gone the storm we will be able to go to the beach.

'Now that the storm is gone we will be able to go the beach.'

Another difference between unaccusative and unergative verbs in Spanish concerns the position of the subject with presentational verbs (Contreras, 1978; Suñer, 1982), although this is an optional rule (Demonte, 1985). Stylistically, subjects of unaccusative verbs show a marked tendency to appear in object position (postposed), as in (12).

12) María llegó ayer / Ayer llegó María. (preferred)

Mary arrived yesterday / *Yesterday arrived Mary.

By contrast, if postposed, subjects of unergative verbs sound odd, unless there is special emphasis in the discourse context.

13) María trabajó ayer (preferred) / *Ayer trabajó María.

Mary worked yesterday / *Yesterday worked Mary.

\section{Methodology}

\section{Participants}

Participants were a control group of 28 Spanish monolingually raised native speakers from a variety of Spanish-speaking countries (henceforth monolinguals), and two experimental groups: 71 English-speaking L2 learners of Spanish (ranging from low intermediate to advanced) and 36 Spanish heritage speakers, or Spanish-English bilinguals of Mexican background living in the USA. Some of the monolinguals were recent arrivals in the USA and spoke some English while the rest were tested in Argentina. To my knowledge, no dialectal variation with respect to the use of unaccusative and unergative verbs has ever been reported in the literature, perhaps because unlike Italian and French, Spanish does not have two perfect auxiliaries. The L2 learners and the 
Table 1 Participants' biographical information

\begin{tabular}{|c|c|c|c|c|c|c|}
\hline & \multicolumn{2}{|c|}{$\begin{array}{l}\text { Monolingual } \\
\text { speakers }(n=28)\end{array}$} & \multicolumn{2}{|c|}{$\begin{array}{l}\text { L2 learners } \\
(n=71)\end{array}$} & \multicolumn{2}{|c|}{$\begin{array}{l}\text { Heritage } \\
\text { speakers }(n=36)\end{array}$} \\
\hline & Age & $\begin{array}{l}\text { Age of first } \\
\text { exposure to } \\
\text { Spanish }\end{array}$ & Age & $\begin{array}{l}\text { Age of first } \\
\text { exposure to } \\
\text { Spanish }\end{array}$ & Age & $\begin{array}{l}\text { Age of first } \\
\text { exposure to } \\
\text { Spanish }\end{array}$ \\
\hline Mean & 31 & birth & 23.08 & 14.56 & 21.4 & birth \\
\hline Range & $19-60$ & & $19-45$ & $12-24$ & $19-26$ & \\
\hline sd & 7.76 & & 5.49 & 3.04 & 2.0 & \\
\hline
\end{tabular}

heritage speakers were enrolled in Spanish and literature classes at a major research university. Although the heritage speakers had not received early schooling in Spanish (as main language of instruction, not as a foreign language), they were taking Spanish as a second language, or as a major area of study. Some of these heritage speakers had recently spent some time in a Spanish-speaking country, ranging from 1 to 7 months. Many of the advanced L2 learners also had some study-abroad experience, ranging from 2 months to 5 years. Information about age, and age of exposure to Spanish, is summarized in Table 1.

\section{Tasks}

All participants, including the monolingual speakers, were first asked to complete a linguistic background questionnaire and a Spanish Proficiency Test (parts of the DELE), consisting of a cloze and a vocabulary part. Based on this test, the L2 learners and the heritage speakers were divided into advanced, intermediate and low intermediate levels. Mean and standard deviations for this classification appear in Table 2.

According to the results of a one-way ANOVA on the proficiency scores, there was a significant difference by groups $(F(2,124)=$ 255.661, $p<0.0001)$. Tukey comparisons indicated statistical differences between the monolinguals and all the other groups. Furthermore, the low intermediate, intermediate and advanced proficiency groups were different from each other. While there were no statistical differences between advanced L2 learners and heritage speakers, or between the low-proficiency L2 learners and heritage speakers, the difference between the means of the intermediate heritage speakers $(36.5)$ and that of the intermediate L2 learners (31.9) was significant $(p<.024)$, due to the greater standard deviations of the L2 learners. 
216 SLA and L1 loss in adult early bilinguals

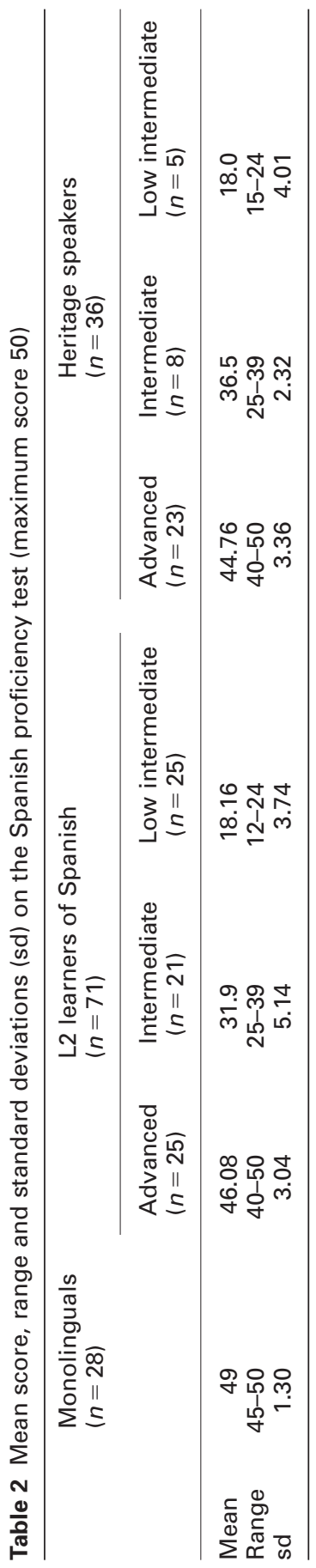


Table 3 Unacusative verbs

\begin{tabular}{|c|c|c|c|c|c|}
\hline \multicolumn{2}{|c|}{ CHANGE OF LOCATION } & \multicolumn{2}{|c|}{ CHANGE OF STATE } & \multicolumn{2}{|c|}{ EXISTENCE OF STATE } \\
\hline llegar & 'arrive' & morir & 'die' & existir & 'exist' \\
\hline salir & 'leave' & desaparecer & 'disappear' & quedar & 'remain' \\
\hline caer & 'fall' & surgir & 'emerge' & faltar & 'lack' \\
\hline
\end{tabular}

Note: Those in the left-hand column are most unaccusative, those in the middle column less so, and those in the right-hand column are least unaccusative.

The main instrument was a grammaticality judgement task (GJT) consisting of a total of 110 sentences (55 grammatical and 55 ungrammatical) presented in randomized order. A scale ranging from 1 (totally unacceptable) to 5 (perfectly acceptable) followed each sentence, so that participants could express different degrees of acceptability. The test included 9 unaccusative verbs, 9 unergative verbs and 10 transitive verbs as distracter items. Within the unaccusative and unergative verbs, there were 3 verbs of different semantic subclasses representing Sorace's (2000b) unaccusative/unergative continuum, ranging from 'core' to 'peripheral' unaccusatives, as in Table 3, and 'core' and 'peripheral' unergatives, as in Table 4. (The test did not include alternating unaccusatives (romper/romperse 'break' (transitive/intransitive).)

All the unaccusative and unergative verbs appeared in the following constructions:

- with preverbal subjects: grammatical for both types of intransitive verbs but preferred for unergatives; as in (12);

- with postverbal subjects: grammatical with unaccusatives but dispreferred with unergatives; as in (13);

- in participial absolutive constructions: grammatical with telic unaccusatives, as in (8), but ungrammatical with atelic unaccusatives (10) and with unergatives, as in (9);

- in bare plural postverbal subject constructions (grammatical with unaccusatives but ungrammatical with unergatives), and in bare plurals with preverbal locatives with unergative verbs (more acceptable than without the locative). ${ }^{6}$ 
Table 4 Unergative verbs

\begin{tabular}{|c|c|c|c|c|c|}
\hline \multicolumn{2}{|c|}{$\begin{array}{l}\text { CONTROLLED PROCESS } \\
\text { (NONMOTIONAL) }\end{array}$} & \multicolumn{2}{|c|}{$\begin{array}{l}\text { CONTROLLED PROCESS } \\
\text { (MOTIONAL) }\end{array}$} & \multicolumn{2}{|c|}{ UNCONTROLLED PROCESS } \\
\hline hablar & 'speak' & correr & 'run' & temblar & 'shiver' \\
\hline cantar & 'sing' & caminar & 'walk' & bostezar & 'yawn' \\
\hline
\end{tabular}

Note: Those in the left hand column are most unergative, those in the middle column less so, and those in the right-hand column are least unergative.

- in the passive construction (ungrammatical for both types of verbs); passives were included because L2 learners have been shown to accept intransitive verbs in passive constructions in English, and it is important to see whether this error is also attested in Spanish.

Before taking the GJT, the learners and the heritage speakers were given a vocabulary task that included all the critical items in the GJT, in which they had to match a verb with a picture. The purpose of this task was to make sure that participants were acquainted with the dictionary meanings of the verbs before they were ready to judge them in sentences. Items that were unknown to a participant were removed from further analysis for that particular participant. Except for few lower proficiency L2 learners, most learners and heritage speakers knew all the lexical items.

\section{Hypotheses}

To formulate the hypotheses, let us start with the assumption that heritage speakers and L2 learners of similar proficiency will behave alike. With respect to the syntactic reflexes of unaccusativity, if low intermediate L2 learners and heritage speakers do not distinguish between unaccusative and unergative verbs, they will assign similar ratings to the two classes of intransitive verbs in the five constructions tested. Specifically, if they assume that all verbs are unergatives, as Oshita (2001) proposed, they will tend to reject unaccusative verbs in participial absolute constructions and in bare plural constructions; they will tend to reject unaccusatives and unergatives in passive sentences; and they will tend to reject unaccusatives and unergatives with postverbal subjects. 
If intermediate learners and heritage speakers have already restructured their grammars and have realized that unaccusatives and unergatives have different underlying syntactic representations, then they will treat both classes of intransitive verbs differently. Specifically, they will correctly accept unaccusative verbs and correctly reject unergative verbs in the participial absolute and bare plural constructions. If, as in English, passive unaccusatives are also attested in Spanish interlanguage grammars at this stage, then these learners and heritage speakers are also expected to incorrectly accept more passive unaccusatives than passive unergatives. Finally, they will accept unaccusatives, but not unergatives with postverbal subjects, and they will rejct unaccusatives with preverbal subjects.

If complete restructuring of interlanguage grammars and native-like competence is possible with unaccusative verbs in Spanish, advanced learners and heritgage speakers should overcome errors typical of the intermediate level, such as, for example, incorrect acceptance of passives, if these occur in Spanish at all.

With respect to the semantics of unaccusativity, if the unaccusative hierarchy is universal, as Sorace (2000b) claims, then its effects should be observable in the acquisition and potential attrition of Spanish as well. In particular, if errors with unaccusatives and unergatives occur, we expect to find more errors or indeterminate judgements with 'peripheral' and 'less core' verbs than with 'core' verbs.

Finally, if native-like knowledge is difficult to achieve in the semantic domain of unaccusativity, as Sorace has claimed, and because previous research on attrition has shown that syntax-semantics and syntax-pragmatics interfaces are more likely to be affected than syntax proper, then we expect L2 learners and heritage speakers to give more determinate judgements on the syntactic, rather than semantic, component of unaccusativity, as revealed by verb-class analyses. In what follows, I present overall results by group first and then break them down by proficiency levels.

\section{Results}

\section{The syntax of unaccusativity}

In this analysis, I focus on how all the unaccusative and unergative verbs were rated overall in the five different constructions, while in the next 
section I break the results down into semantic subclasses. Mean acceptability scores were submitted to a three-way ANOVA with repeated measures, with verb (unaccusative and unergative) and constructions (preverbal subjects, postverbal subjects, absolutive constructions, postverbal bare plural subjects and passives) as the within subjects factors, and group (native speakers, L2 learners and heritage speakers) as the between subjects factor. There was a main effect for verb $(F(1,128)=787.555, p<0.0001)$, for construction $(F(4,128)=312.842$, $p<0.0001)$ and for group $(F(2,128)=154.441, p<0.0001)$. All other possible interactions were significant at the alpha $<0.05$ level. Given that a main objective of this study is to investigate whether the experimental groups distinguish between unaccusative and unergative verbs in the same construction, these contrasts were analysed through paired sample $t$-tests, and Bonferroni corrections. Because there was a significant three-way interaction, I followed this up with simple main effects for construction and group. When differences between groups are reported, these were obtained through one-way ANOVAs and selective post hoc pairwise comparisons.

Let us start by showing the overall pattern of response of the monolingual native speakers, displayed in Figure 1. As can be seen in this figure, the monolingual controls rated sentences with preverbal subjects equally acceptable with the two types of verbs, with mean acceptability scores above 4.9. With postverbal subjects, however, there

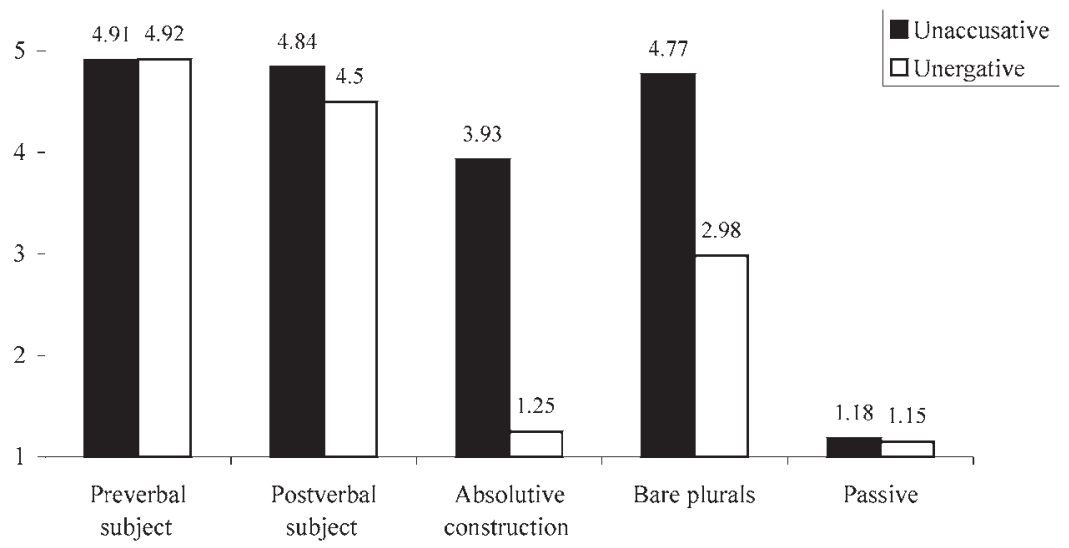

Figure 1 Monolingual Spanish speakers $(n=28)$ : mean acceptability scores 
$5-$

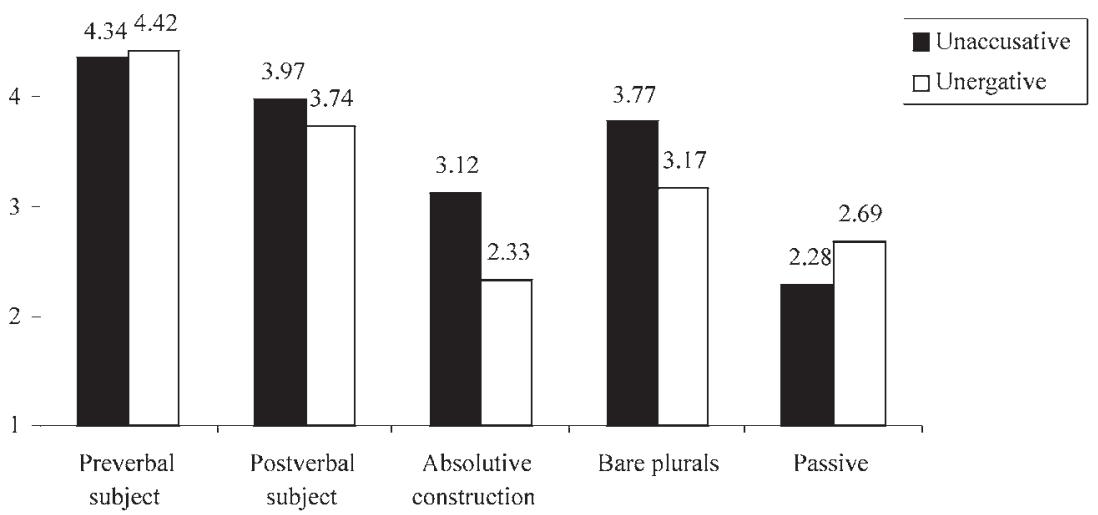

Figure 2 English-speaking L2 learners of Spanish $(n=71)$ : mean acceptability scores

was a slight preference for unaccusatives as opposed to unergatives, and this difference was significant according to paired sample $t$-tests $(t=.413, d f=54, p<0.029) .{ }^{7}$ Recall that only telic unaccusative verbs (verbs of directed motion like caer 'to fall' and verbs of appearance like aparecer 'appear') are grammatical in the absolutive construction. Atelic unaccusatives (verbs of existence like existir 'exist') and all the unergatives are ungrammatical. For this comparison, the analysis was performed between the two classes of telic unaccusatives and all the unergatives. (The results of the atelic unaccusatives, which do not accept the construction, are discussed in the individual verb analysis below). As predicted by proposals in the syntactic literature, telic unaccusatives were rated significantly more acceptable than unergatives in the participial absolute construction $(t=.547, d f=54, p$ $<0.011$ ), and so were unaccusatives in constructions with postverbal bare plural subjects when compared to their unergative counterparts $(t=624, d f=54, p<0.0001)$. Finally, native speakers rated unaccusative and unergative verbs equally unacceptable in passive constructions, with mean acceptability scores below 1.20.

Figure 2 shows the pattern of response of the L2 learners, which is very similar to that of the native speakers. For example, there were 
no significant differences between sentences with preverbal subjects $(t=-1.232, d f=140, p<0.222)$, while differences between unaccusatives and unergatives with postverbal subjects, in the absolutive construction and with bare plural postverbal subjects, were all significant at the $p<0.0001$ level. The main difference between the native speakers and the L2 learns was the stronger acceptance of passives by the latter (well above 2.2). However, the difference between passive unaccusatives and unergatives turned out to be nonsignificant.

Figure 3 displays the results of the heritgage speakers, who also showed robust knowledge of the syntax of unaccusativity. Like the monolingual speakers, the heritage speakers rated unaccusatives and unergatives with preverbal subjects equally acceptable. However, there were significant differences between unaccusatives and unergative verbs with postverbal subjects $(p<0.025)$, in the absolutive construction $(p<0.0001)$ and with bare plural postverbal subjects $(p<0.001)$. The rate of acceptability of unaccusatives and unergatives (close to 1.6) was stronger than that of the monolingual native speakers, and weaker than that of the L2 learners.

Let us summarize the results so far. The L2 learners and heritage speakers have robust knowledge of the syntactic reflexes of unaccusativity in Spanish, since they correctly discriminated syntactically between unaccusative and unergative verbs with postverbal subjects, in the absolutive construction, and with postverbal bare plural subjects.

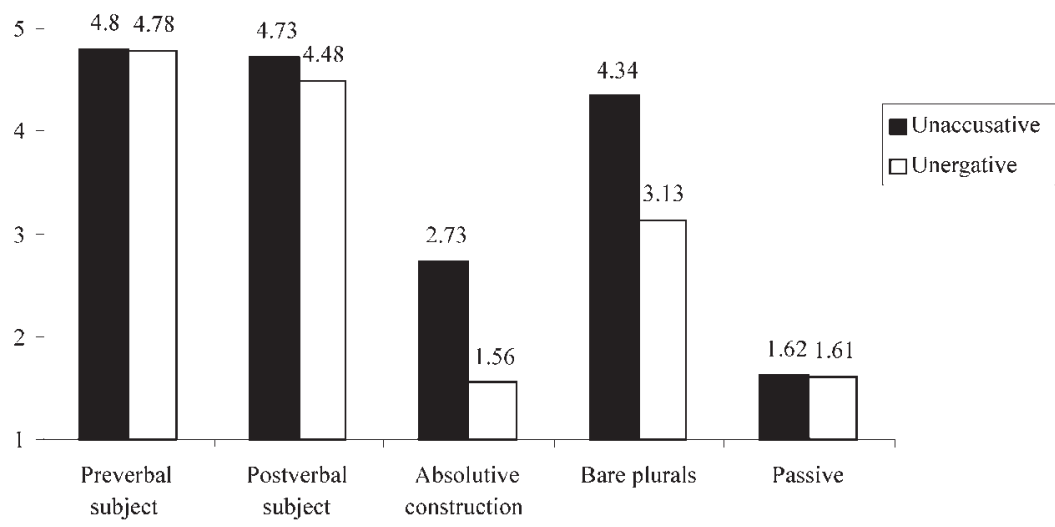


The most notable difference between the three groups is the acceptance rate of ungrammatical passive unaccusatives and unergatives. While the heritage speakers and the monolingual speakers tended to reject passive unaccusatives and unergatives (with ratings below 1.60), the L2 learners gave acceptability scores close to 2.7 . The acceptability rate that heritage speakers assigned to passives was statistically higher than the rates assigned by the native speakers $(p<0.037)$, but statistically lower than the rates of the L2 learners $(p<0.028)$, according to ANOVA. These overall group results are consistent with the results of another study comparing the interpretation of tense and aspect morphology in these two populations (Montrul, 2004b), where I suggested that heritage speakers and advanced L2 learners were very similar with respect to the type of linguistic knowledge they had, and what they appeared to lack.

However, since L2 acquisition studies have also shown that knowledge of unaccusativity was not quite evident in low-proficiency learners, but clearly emerged at the intermediate level (Oshita, 2001), it is therefore important to investigate whether L2 learners and heritage speakers indeed display similar linguistic knowledge when proficiency level is taken into account.

\section{Results by proficiency levels}

Figure 4 shows the mean judgements on sentences with preverbal subjects, which are grammatical with unaccusatives and unergative verbs. All proficiency levels in the L2 learner and heritage speaker groups

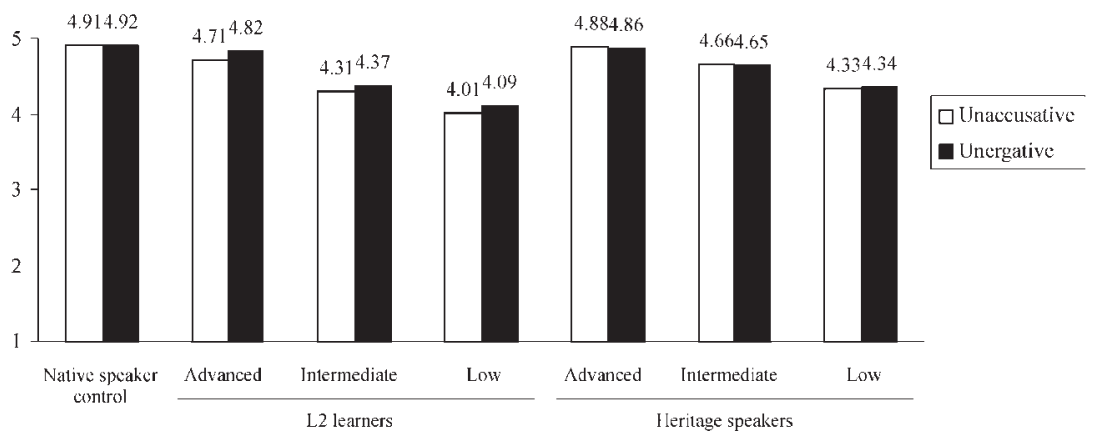

Figure 4 Mean acceptability scores on sentences with preverbal subjects 


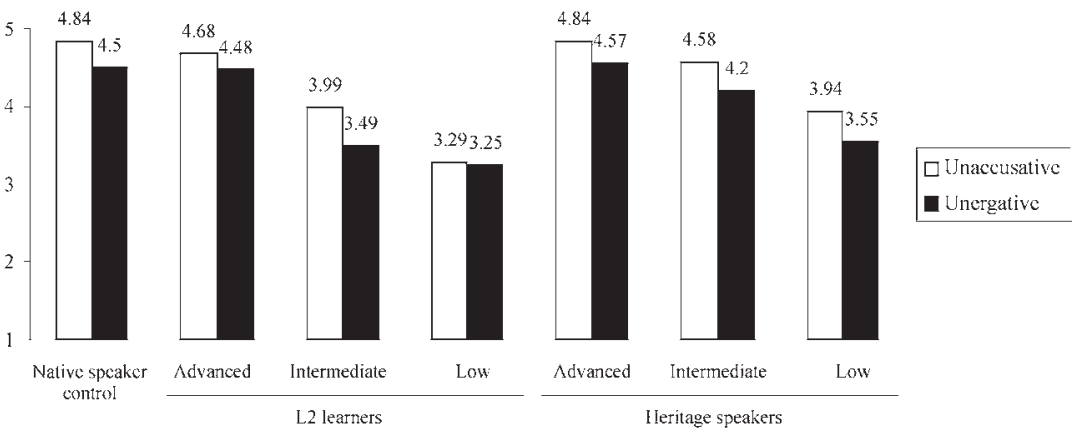

Figure 5 Mean acceptability scores on sentences with postverbal subjects

were accurate on these sentences, rating them alike. The results of unaccusative and unergative verb sentences with postverbal subjects appear in Figure 5. Recall that there is a stylistic preference for unaccusatives with postverbal subjects, although the two verb types are grammatical in this construction. With the exception of the low proficiency L2 learners, who did not discriminate between unaccusative and unergative verbs with postverbal subjects, all the other groups assigned statistically higher ratings to unaccusatives than to unergatives.

Figure 6 displays the results of the absolutive construction. Except for the low proficiency L2 learners, who did not discriminate between the two verb classes $(p<0.554)$, the intermediate and advanced L2 learners groups and all the heritage speakers showed the same pattern

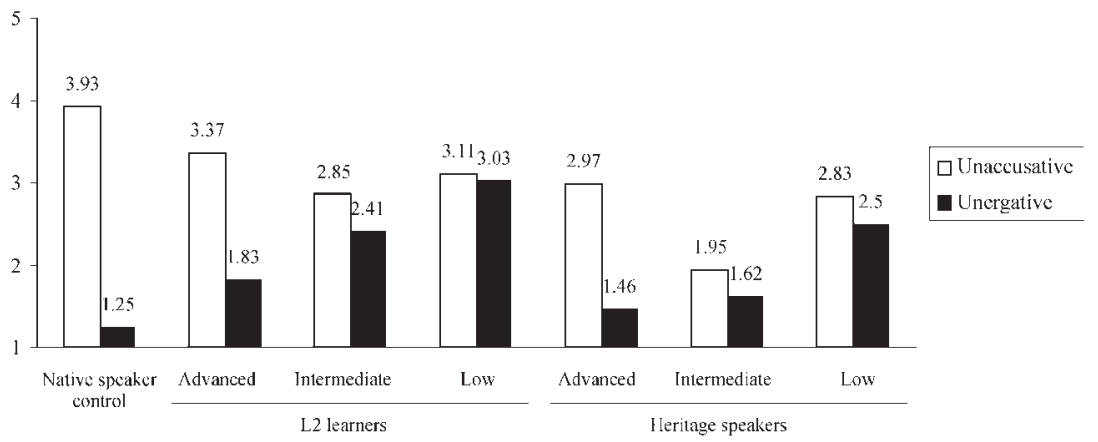

Figure 6 Mean acceptability scores on the absolutive construction 


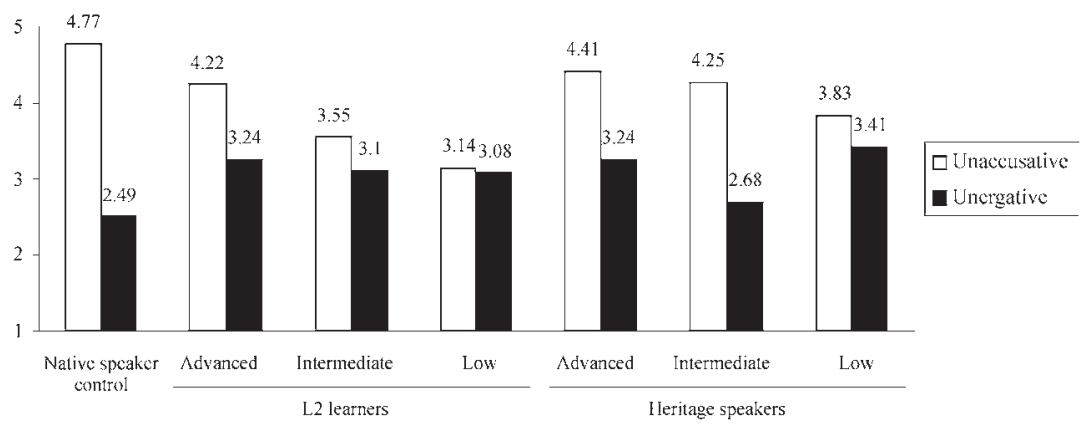

Figure 7 Mean acceptability scores on sentences with bare plural postverbal subjects

of response as the native speakers, assigning statistically higher ratings to unaccusatives than to unergatives.

Figure 7 presents the results of postverbal bare plural subjects, which are also acceptable with unaccusatives and less acceptable with unergatives. The contrast between the two verbs turned out significant for the monolinguals, the heritage speakers, and the intermediate and advanced L2 learners. The contrast was not significant for the low intermediate L2 group ( $p<0.102)$. Although the low proficiency heritage speakers also rated unaccusatives higher than unergatives, and the difference between the two means was greater than for the L2 learners, the contrast did not reach significance in this case, due possibly to the small number of subjects in this group $(n=5)$.

Figure 8 shows the results of the passive voice. The monolinguals, the advanced L2 learners and the advanced heritage speakers
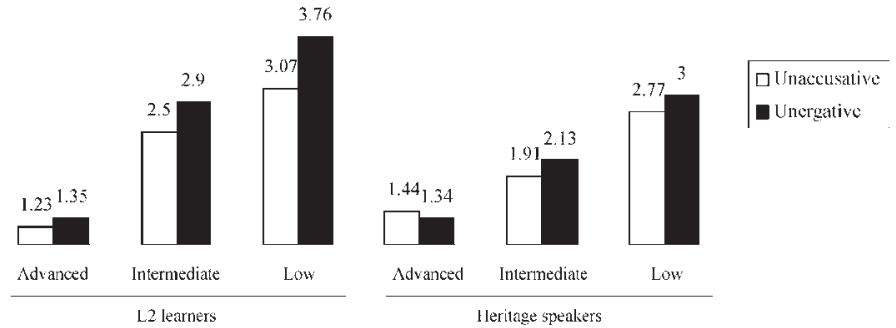

Figure 8 Mean acceptability scores on passives 
correctly assigned very weak acceptability ratings to these sentences. By contrast, the intermediate and low proficiency L2 learners and heritage speakers assigned stronger ratings than the native speakers and the two advanced groups. In general, and as shown by the overall results, the L2 learners were more accepting of these ungrammatical sentences than the heritage speakers.

In short, these results by proficiency levels show that qualitative differences between the heritage speakers and L2 learners were only found with the low proficiency groups. By and large, these L2 learners appear to show no syntactic discrimination between unaccusatives and unergatives in any of the constructions tested, while low proficiency heritage speakers showed the predicted pattern.

\section{The semantics of unaccusativity}

Let us now focus on the different subclasses of verbs, to see the extent to which the patterns of responses of the three groups conform to Sorace's unaccusativity hierarchy. Here, I only focus on bare plurals (Figure 9), absolutive constructions (Figure 10) and passives (Figure 11), and first show overall results by group, by verb and by construction, followed by a presentation by proficiency groups.

Postverbal bare plural subjects are grammatical with all unaccusatives and ungrammatical for unergatives. Two-way ANOVAs were run with group and semantic subclasses as factors. (There were 3 verbs per sub-

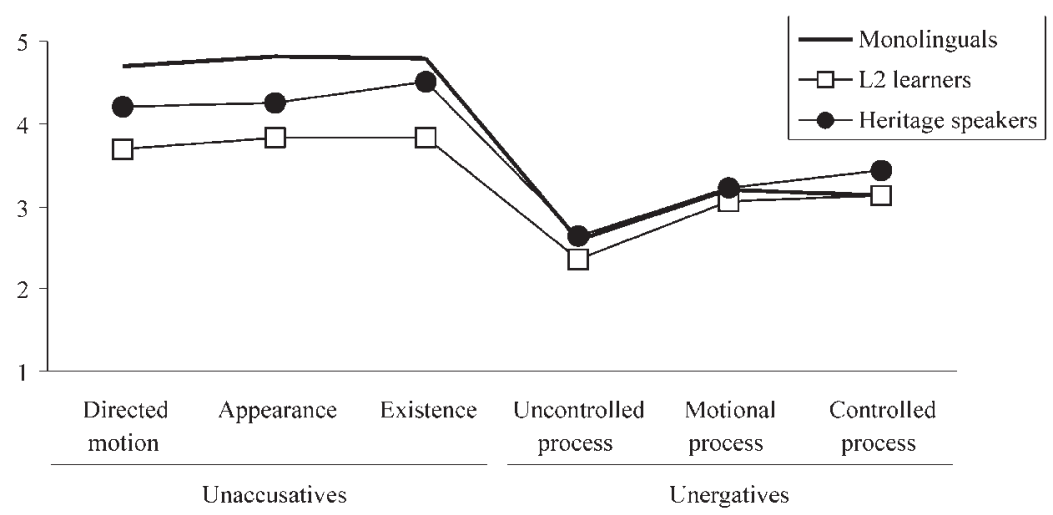

Figure 9 Mean ratings on sentences with bare plural subjects by verb class 


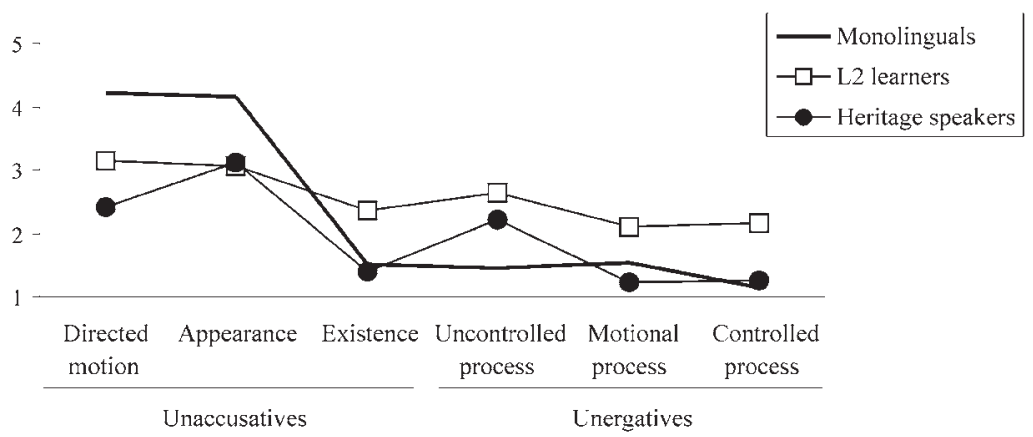

Figure 10 Mean ratings on the absolutive construction by verb class

class.) For the native speakers, there was an effect by verb and a verb by subclass interaction. Unaccusatives were assigned statistically higher ratings than unergatives $(F(1,27)=120.610, p<0.0001)$. While there were no differences between the ratings for unaccusative verbs of directed motion (mean 4.69), of appearance, (4.82) and of existence (4.8), there were differences among the unergative classes $(F(2,26)=$ $4.95, p<0.015)$. Uncontrolled process unergatives received statistically lower ratings than motional process $(p<0.001)$ and controlled process unergatives $(p<0.033)$, and this is the opposite trend predicated by the unaccusativity hierarchy.

The heritage speakers and the L2 learners showed the exact same pattern of response as the monolingual speakers: unaccusatives were

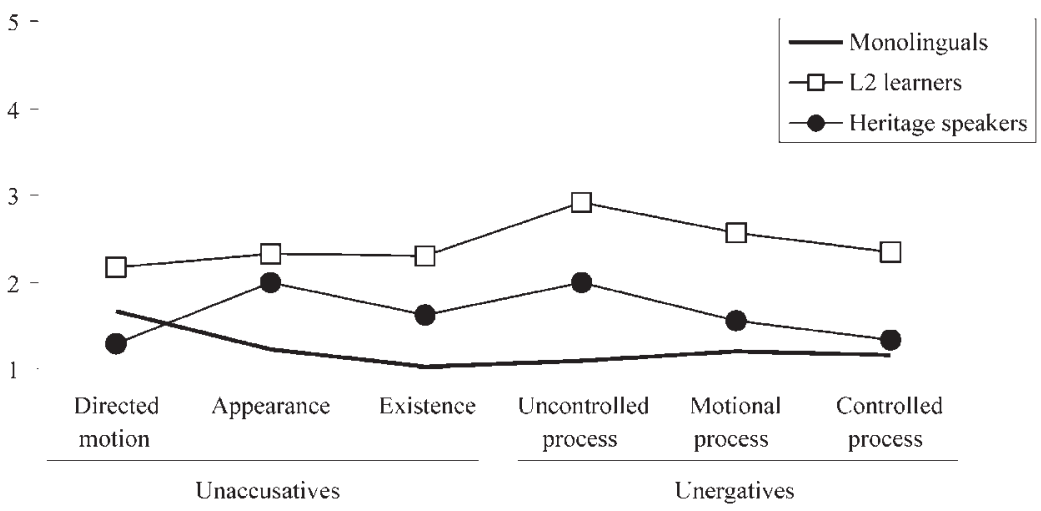

Figure 11 Mean ratings on passive sentences by verb class 
assigned statistically higher ratings than unergatives; there were no differences between the ratings for the three unaccusative classes; and uncontrolled process unergatives received statistically lower ratings than the other unergatives. The results of the uncontrolled process unergatives are consistent with the variability expected under Sorace's unaccusativity hierarchy, since these are 'peripheral' unergatives. In terms of groups, monolinguals, heritage speakers and L2 learners were significantly different from each other with the three subclasses of unaccusative verbs $(F(2,128)=545.348, p<0.0001)$ : monolinguals assigned the strongest ratings, L2 learners the lowest and heritage speakers fell in between.

Figure 10 focuses on the results of the absolutive construction. Unaccusative verbs of directed motion and of appearance are acceptable in this construction, whereas unaccusative verbs of existence and the unergative classes (uncontrolled process, motional process and controlled process) are not. The results of the monolinguals display precisely this pattern: verbs of directed motion and of appearance received similar ratings (above 4), while the atelic unaccusatives (verbs of existence) and the three unergative classes received ratings below 1.5. These differences were significant according to an ANOVA with repeated measures $(F(5,23)=245.637, p<0.0001)$. Although the ratings of the L2 learners are less determinate than those of the other two groups, like the monolinguals, the L2 learners also rated unaccusatives of directed motion (3.13) and of appearance (3.07) statistically higher than unaccusatives of existence (2.36) $(p<0.0001)$. Among the unergatives, uncontrolled process verbs (which are 'peripheral' unergatives in Sorace's hierarchy), received statistically higher ratings (2.63) than motional (2.11) and controlled process verbs (2.15). The heritage speakers displayed the most variability. The three unaccusative subclasses were rated significantly different from each other according to $t$-tests $(p<0.0001)$. Although these speakers clearly recognized that existence verbs are the least acceptable in this construction, they also rated the 'core' directed motion verbs lower (2.4) than 'less core' appearance verbs, which received a rating of 3.12. Crucially for Sorace's hierarchy, however, the 'peripheral' existence verbs were rated lower (1.14) than the 'core' directed motion verbs. As for the unergative verbs, just like the L2 learners, the peripheral uncontrolled process 
verbs received stronger ratings (2.20) than the other two unergative subclasses, which had ratings of 1.23 and 1.24.

Investigated through ANOVAs and Tukey post hoc procedures, group differences showed that the L2 learners and the monolingual speakers differed significantly from each other with all the subclasses of unaccusatives and unergatives: the L2 learners gave weaker judgements than the monolinguals. The heritage speakers were statistically different from the monolinguals with directed motion $(p<0.002)$ and appearance unaccusatives $(p<0.001)$, and with uncontrolled process unergatives $(p<0.0001)$. The heritage speakers and the L2 learners assigned statistically similar ratings to appearance unaccusatives and uncontrolled process unergatives.

Finally, Figure 11 displays the ratings for ungrammatical unaccusative and unergative verbs in the passive construction. As can be seen, the native speakers assigned very weak ratings to these sentences, although they rated core unaccusatives more acceptable (mean 1.66) than all the other verbs (appearance 1.23, existence 1.03, uncontrolled process 1.09 , motional process 1.2 and controlled process 1.15$)(p<$ $0.016)$. The $\mathrm{L} 2$ learners rated passives with all the unaccusative verbs statistically alike, with ratings ranging from 2.1 to 2.3. Among the unergatives, the 'peripheral' uncontrolled process verbs received stronger ratings (2.91) than all the unaccusatives and the two other classes of unergatives $(p<0.001)$. The ratings for controlled process unergatives (2.56) were statistically different from the 'core' controlled process unergatives $(2.33)(p<0.009)$. The heritage speakers displayed greater variability with all the verbs. The three unaccusative subclasses were rated statistically different from each other, and so were the unergative ones. The 'less core' appearance unaccusatives and the 'peripheral' uncontrolled processes verbs received the stronger ratings, above 2. Overall, there were also significant differences among the three groups $(F(2,128)=445.757, p<0.0001)$. The difference between the monolinguals and the heritage speakers almost reached significance $(p<0.054)$, particularly due to the higher acceptability ratings the heritage speakers assigned to the verbs in the middle of the hierarchy: appearance and existence unaccusatives, and uncontrolled process unergatives. The L2 learners were statistically different from the monolinguals $(p<0.001)$ and the heritage speakers $(p<0.001)$. 


\section{Verbs by proficiency}

In this section we focus on an analysis of verbs by proficiency level, to see whether L2 learners and heritage speakers differ from each other when this variable is taken into account. A repeated measures two-way ANOVA revealed a main effect for proficiency $(F(2,128)=154.047$, $p<0.0001)$. When the two experimental groups were compared with each other, advanced heritage speakers gave overall higher ratings than advanced L2 learners $(F(1,46)=701.069, p<0.0001)$, and the same statistical pattern was observed with the intermediate $(F(1,26)=$ $183.908, p<0.0001)$ and low $(F(1,29)=888.351 p<0.0001)$ levels of proficiency.

Let us now look at individual constructions once more to see the extent to which the different levels of proficiency show semantic discrimination, as revealed by ratings on subclasses of verbs. Table 5 presents the ratings for the bare plural construction. Numbers in bold indicate variability, or ratings that are statistically different at the $p<$ 0.05 level from the ratings of the other verbs in the same class. The two advanced groups and the monolinguals showed a similar pattern of response, rating uncontrolled process verbs statistically lower than the other unergatives. The intermediate L2 learners rated uncontrolled process unergatives statistically lower than the other two unergative subclasses. By contrast, the heritage speakers, who assigned higher ratings to all verbs, rated uncontrolled process unergatives and existence unaccusatives, the most peripheral classes in Sorace's hierarchy, differently from other verbs of their respective classes. As for the lowest proficiency levels, the L2 learners rated all verbs statistically, alike, suggesting that they did not discriminate semantic subclasses in this construction, while the heritage speaker counterparts assigned differential ratings to the 'peripheral' unaccusatives and unergatives, just like the intermediate heritage speakers.

The results of the absolutive construction, presented in Table 6, show that the monolinguals and the two advanced groups correctly assigned lower ratings to unaccusative verbs of existence, since these are not grammatical in this construction. However, the L2 learners and the heritage speakers also rated uncontrolled process verbs statistically higher than the other two other subclasses of unergatives. Furthermore, the advanced heritage speakers rated directed motion unaccusatives 


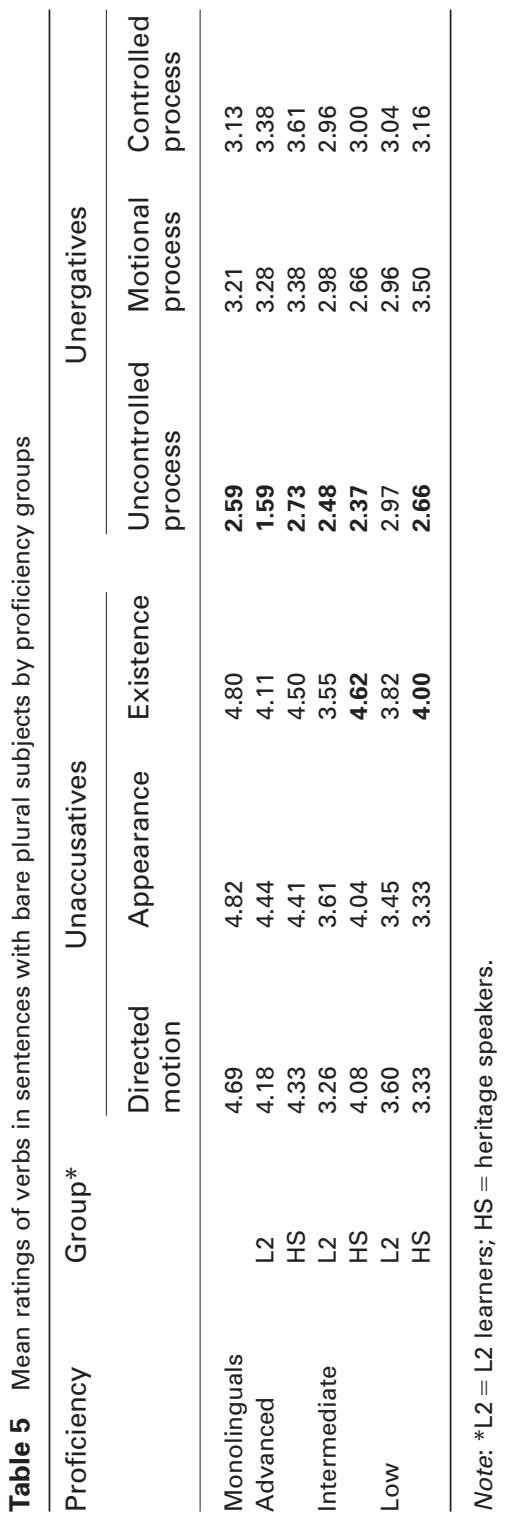




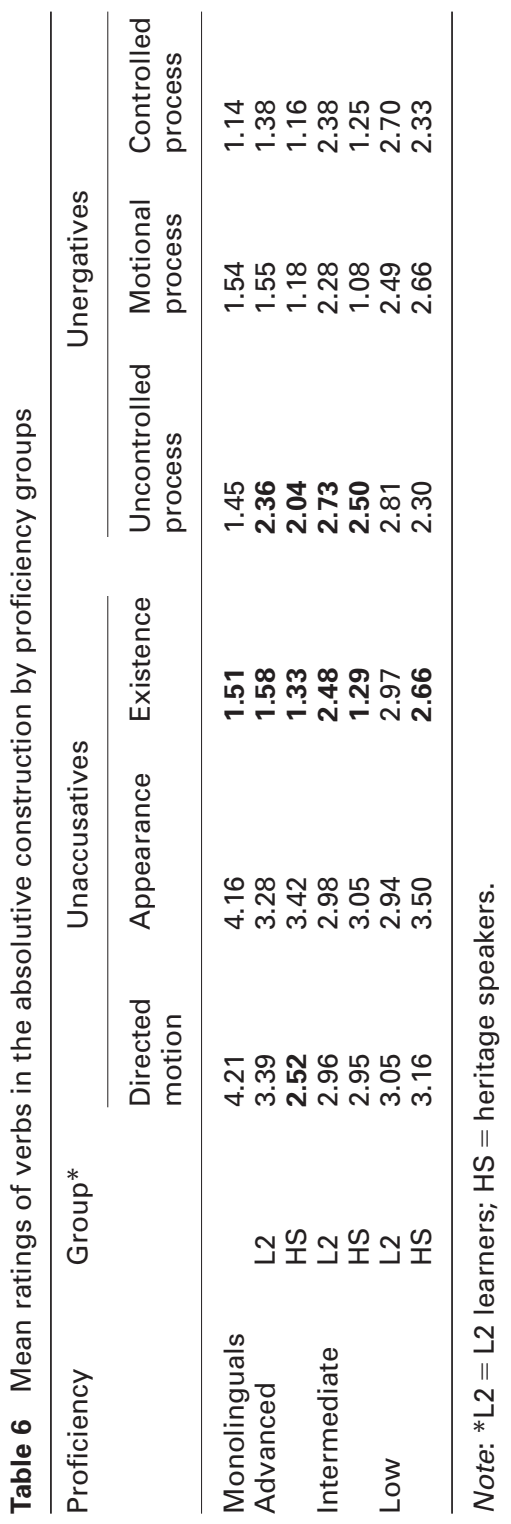




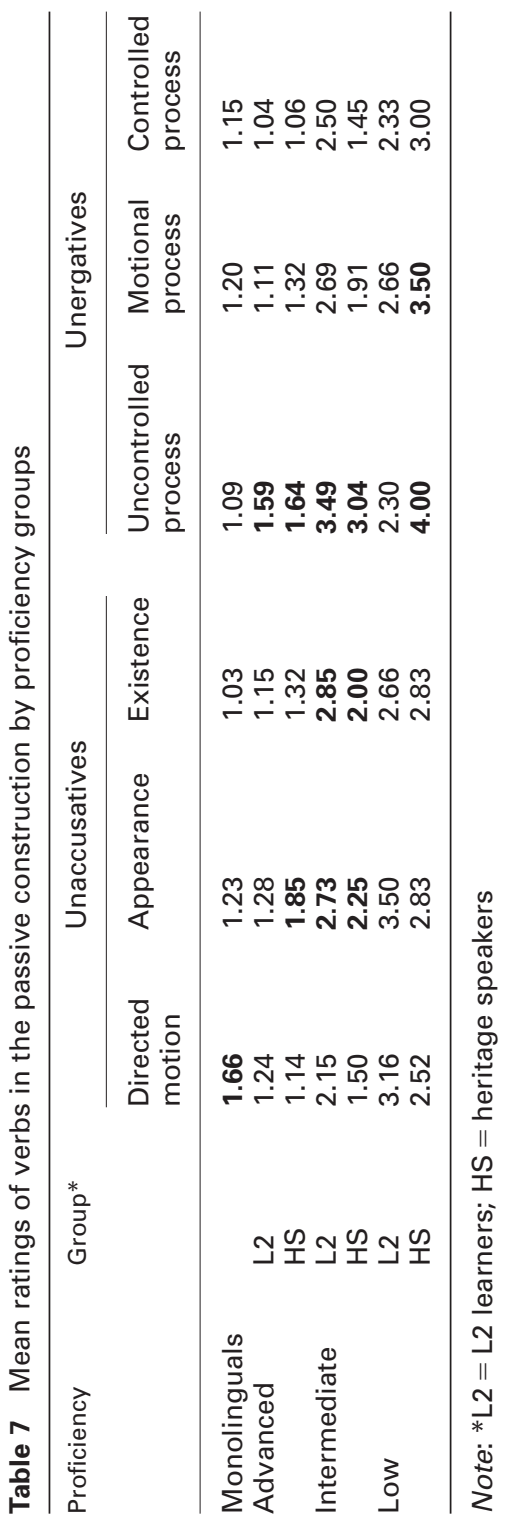


statistically lower than appearance unaccusatives. The two intermediate groups showed the same pattern of variability: they rated existence unaccusative statistically lower than the other two unaccusative subclasses, and uncontrolled process unergatives higher than the two other unergative subclasses. As for the lower proficiency groups, the L2 learners rated all unaccusatives and unergatives statistically alike, while the heritage speakers correctly rated existence unaccusatives lower than the other unaccusatives. Also with this construction, it appears that a clear difference between L2 learners and heritage speakers emerges at this level: while the L2 learners appear to have no semantic discrimination among verbs (and rated from alike), the heritage speakers do.

The results of the passive, displayed in Table 7 , show that most of the variability in the ratings of different verbs occurred with appearance and existence unaccusatives and the uncontrolled process unergatives, that is, the 'peripheral' and 'less core' classes. This was the case for the advanced and intermediate groups. As for the lowest proficiency groups, while the L2 learners rated all verbs alike within each class, the heritage speakers displayed the greatest variability with uncontrolled process unergatives. Overall, the verb by proficiency analysis revealed that heritage speakers displayed more semantic discrimination and more variability than L2 learners. An important qualitative difference emerged at the lowest level of proficiency: while the heritage speakers demonstrated some semantic discrimination of verbs, the L2 learners did not. Therefore, despite having scored similarly in a proficiency test, the heritage speakers appear to know more about the semantics and syntax of unaccusativity in Spanish than their L2 learner counterparts.

\section{Discussion}

In examining the long-standing effects of incomplete acquisition in early bilinguals and comparing them with typical L2 language learners, this study has shown that, overall, L2 learners and heritage speakers are very similar in the type of linguistic competence they have, yet important differences emerged when proficiency level was factored in, particularly at the low intermediate level.

Intermediate and advanced L2 learners and heritage speakers displayed robust knowledge of the syntax of unaccusativity in Spanish. 
These participants showed the exact same pattern of discrimination and response as the monolingual native speaker controls. In other words, participants rated unaccusatives with preverbal and postverbal subjects as grammatical, but accurately perceived a stylistic difference between the two classes of verbs with postverbal subjects. All these participants rated unaccusative verbs statistically higher than unergative verbs. They also recognized that unaccusatives are acceptable in the absolutive construction (with the exception of existence verbs) and in the postverbal bare plural construction, while unergatives are less so. Finally, intermediate and advanced L2 learners and heritage speakers recognized that unaccusative and unergatives are not acceptable in passive constructions, although the intermediate group accepted this error much more that the other groups. Even though the intermediated groups accepted more ungrammatical sentences than the advanced groups and the monolinguals, they still showed reliable discriminations between the two classes of verbs. In short, despite overall quantitative differences, heritage speakers and L2 learners did not differ qualitatively, and both groups displayed robust syntactic knowledge of unaccusativity in Spanish.

With respect to the semantics of unaccusativity, advanced and intermediate L2 learners and heritage speakers also showed sensitivity to semantic subclasses. In general, heritage speakers displayed more variable judgements by semantic subclasses than L2 learners and monolingual speakers. When variability occurred, this was consistent with the predictions of the unaccusativity hierarchy: it was most prominent with the 'less core' and 'peripheral' unaccusatives and unergatives than the 'core' ones. For examples, the 'peripheral' uncontrolled process unergatives and existence unaccusatives were the subclasses that received most variable ratings in the absolutive construction, the bare plurals construction and passives. Appearance unaccusatives received variable ratings only in the passive construction. These patterns of responses are consistent with Sorace's (2000b) unaccusativity hierarchy.

The results of existence unaccusatives are also consistent with what Polinsky (1997) reported for American Russian speakers, both incomplete learners of Russian and 'forgetters', in her terminology. Polinsky's results show that attrition affects the genitive of negation in Russian (an unaccusative diagnostic), especially in cases where it is obligatory and highly frequent, as with existential predicates and verbs 
of existence. However, a reviewer questioned whether in fact the variable results of uncontrolled process unergatives reflected in this study as compared to the other two classes of unergatives (controlled process and motional) are due to the unaccusativity hierarchy or to other syntactic factors. Uncontrolled process verbs are always intransitive (I trembled), while the other two unergative classes can take objects on occasion (sing a song, run a mile). But the fact that controlled process and motional unergatives can on occasion the transitive, reinforces the perception of these verbs as more 'agentive' than uncontrolled process verbs. Because agentivity is strongly aligned with unergativity, this is not suprising. As Sorace (2000) explains, the notions of agentivity and telicity lie at the heart of the semantic hierarchy. Therefore, the semantics and the syntax of these verbs are related.

An important difference between L 2 learners and heritage speakers emerged at the low proficiency level, however. While the heritage speakers discriminated syntactically between the two verb classes in sentences with postverbal subjects, the participial absolutive construction and postverbal bare plural subjects, the L2 learners did not show any type of discrimination, rating the two classes statistically alike in all these constructions. It was also not the case that they treated all verbs as unergatives, as Oshita (2001) claimed, or at least it is very hard to tell from the pattern of results obtained from this group.

While the two groups accepted ungrammatical passive sentences with the two classes of verbs, the L2 learners' ratings were statistically stronger than those assigned by the heritage speakers. In the verb-class analysis, a similar pattern emerged: while the heritage speakers displayed some semantic discrimination of verbs, the L2 learners did not. For example, like intermediate and advanced participants, the low proficiency heritage speakers rated existence unaccusatives less acceptable than the other unaccusatives in the absolutive construction, while the low intermediate L2 learners rated them like all the other verbs in the two classes.

Overall, the results of the L2 learners and the heritage speakers showed that they displayed robust knowledge of the syntax of unaccusativity, yet variation and indeterminacy was most notable with the semantics of unaccusativity, as revealed in the verb subclass analyses. Perhaps it is this semantic indeterminacy, rather than syntax, that 
contributes to 'incomplete' knowledge. This finding is consistent with observations made both in language acquisition and in language attrition studies: that form (syntax) is stable and easy to acquire/maintain, while meaning is less so (Sorace, 2000a; Naigles, 2002).

However, in light of the different results of the low proficiency L2 learner and heritage speaker groups, the first question that arises is whether the results obtained are due to the particular instrument used to classify participants into different levels, or to other factors. Let us consider the first possibility. The proficiency measure used was a prototypical pedagogical tool: a cloze passage with four options per answer and a multiple choice vocabulary part, both parts taken from a version of the DELEs (Diploma of Spanish as a Foreign Language). The DELE is the official accreditation degree of fluency in the Spanish language, issued and recognized by the Ministry of Education, Culture and Sport of Spain. The same version of the test used in this study has already been used in a variety of L2 acquisition studies (see, amongst others, Duffield and White, 1999; Bruhn de Garavito, 2000; Montrul and Slabakova, 2002; 2003; and has proven quite suitable to determine proficiency levels for L2 learners, and to predict linguistic performance in this population.

However, this test might not be entirely suitable to predict the linguistic performance of heritage speakers or early bilinguals, especially those of apparent lower proficiency. An important difference between classroom L2 learners like the ones tested in this experiment and heritage speakers, is that L2 learners have learned the language in a formal setting and are used to taking this type of discrete point grammatical tests. By contrasts, the heritage speakers learned Spanish naturalistically at home in early childhood and received almost no schooling in that language. Therefore, they may not possess the explicit metalinguistic knowledge that typically develops through literacy and the study of language as an object.

We know that monolingual children's ability to understand language and to talk about language as an object, or metalinguistic awareness, develops gradually during the pre-school years but clearly blooms when children learn to read (Bialystok, 2001). We also know from research on phonological, lexical, semantic and syntactic awareness that pre-school bilingual children have been shown to be metalinguistically more 
sophisticated than monolingual children because these children implicitly focus on linguistic form early in linguistic development (for a review and for counterarguments, see Bialystok, 2001.) However, the types of 'explicit' metalinguistic awareness or knowledge required to complete language tests typical of second language classrooms or grammar courses (i.e., fill in blanks with the correct grammatical form, choose the correct form of the verb or the right word given a context, etc.) is developed and practised at school, when children work on their literacy skills (reading and writing) and study language as an object in language arts classes or in second language classrooms. Most of the heritage speakers tested in this study - and particularly those five individuals who scored the lowest on the proficiency measure - missed the opportunity to develop literacy skills early in Spanish, and whatever they know today is through reacquiring the language in a formal context in college. Those that scored at the advanced level used Spanish more often and had taken more classes in Spanish language and literature than the lowest proficiency speakers, who were found in intermediate language classes. Clearly, the speakers who performed at the lowest levels did not have as much experience as the L2 learners with explicit metalinguistic knowledge of grammar, spelling, reading and writing in Spanish. Therefore, a proficiency test like the one administered, which relies on making grammatical and vocabulary choices, might not be the best linguistic assessment tool for this particular population.

The other possibility that I would like to consider is that heritage speakers are in fact linguistically superior to L2 learners, even when, in common with L2 learners, they do not reach the same criterial levels as monolingually raised native speakers, particularly in speech, reading on writing. While the proficiency test was not able to detect the linguistic superiority of the low proficiency group, this was clearly demonstrated by the acceptability judgement measure probing into very subtle areas of linguistic knowledge that do not fall within the typical morphosyntactic structures taught and practised in language classrooms (i.e., gender and number nominal morphology, verb tenses, etc.). To the extent that the instrument used to test unaccusativity can be said to tap more 'implicit' than 'explicit' grammatical knowledge, knowledge that is crucially not available to metalinguistic awareness, then it is safe to 
conclude that heritage speakers have very sophisticated linguistic knowledge of syntax and semantics, even when the long-lasting effects of reduced input in early childhood are obvious in other linguistic domains (vocabulary, morphological errors, semantic interpretations, etc.). The reason for this linguistic superiority must lie in yet another crucial difference between heritage speakers and post-puberty second language learners, such as age of acquisition and nature and timing of input.

The critical period hypothesis, the notion that there is a maturationally determined time in early childhood during which input is crucial to develop linguistic skills, at least in L1 acquisition, had often been invoked to explain why adult L2 learners rarely reach the level of linguistic competence and performance of native speakers (see, among many other's Bley-Vroman, 1990; Johnson and Newport, 1991). According to Meisel (1997; 2001), maturational mechanisms would also explain that early bilinguals (our heritage speakers) have linguistic knowledge that has been acquired early in childhood and through the operation of Universal Grammar, whereas Universal Grammar is not implicated at all in L2 acquisition. However, this explanation is not satisfactory to explain all the results of the present study, since the longlasting effects of reduced input in one of the languages of bilinguals during early childhood also has adverse effects in this population. As argued by Hyltenstam (1992), Montrul (2002) and Hyltenstam and Abrahamsson (2003), it appears that learning a language before puberty is a necessary but not sufficient condition for successful attainment at the native-speaker level. The pattern of responses assigned by the intermediate and advanced heritage speakers in this study were very similar to that of L2 learners and still differed significantly from that of monolinguals, at least quantitatively. It appears that the amount and nature of input (in frequency and quality) plays a more decisive role in bilingual acquisition than in monolingual acquisition, if these children are to develop balanced proficiency or maintain the two languages to the same degree. Indeed, much research in early childhood bilingualism has suggested that bilingual development is typically unbalanced, with the weaker language developing very much like a second language, as judged by processing delays, degree of fluency and types of language errors made (Schlyter, 1993; Kohnert et al., 1999; Kohnert and Bates, 
2002). The results of the intermediate and advanced speakers presented in this study and in others (Montrul, 2002; 2004b) suggest that unbalanced development during school age can have long-lasting effects on the weaker language when these bilinguals reach adulthood.

At the same time, a key finding of this study is that it is timing of input what appears to be crucial. Despite similarities in many areas of linguistic performance, heritage speakers hear Spanish since birth, whereas L2 learners do not typically receive exposure in this language until after puberty. The low proficiency heritage speakers in the current study were still superior in the type of linguistic representations they manifested. This suggests that knowledge of the linguistic area investigated here - a universal aspect of the syntax-semantics interface - develops very early in life (before age 4), as different studies with monolingual children have shown (Synder et al., 1995; van Hout, 1996; Borer and Wexler, 1997; Bel, 2001). Assuming that heritage speakers hear and use more Spanish at home before entering school, it is possible to suggest that knowledge of unaccusativity develops then, at that early period, and this syntactic knowledge is not particularly dependent on the development of literacy skills in the school years.

The findings of this study confirm and complement the findings of a recent study by $\mathrm{Au}$ et al. (2002) on the advantage of receiving input in a language early in childhood. Au et al. (2002) tested phonological and morphosyntactic abilities of typical L2 learners of Spanish (exposed to Spanish after age 14) and Spanish heritage speakers of very limited proficiency in Spanish (even more limited than the low proficiency speakers tested here), but who heard Spanish spoken at home early in childhood. Results showed that the heritage speakers performed significantly better than L2 learner and closer to native speakers in the phonology and pronunciation test on voice-onset time (VOT) values, while performance on the morphosyntactic instrument testing gender and number were similarly inaccurate for the two groups. The authors concluded that even interrupted acquisition during childhood can have long-lasting benefits in some linguistic areas, especially when heritage speakers are trying to reacquire their family language in a second language class. Similarly, the results of the present study show that in addition to 
phonology, early exposure to the language has an effect on aspects of syntax and semantics that are typically not observable in spontaneous production, but can only be revealed by using the tools of linguistic theory. This dormant advantage is, apparently, only observable when we focus on those individuals with the lowest levels of proficiency in the language.

\section{Conclusions}

In attempting to pinpoint vulnerable structural areas of grammatical development, this study has shown that the phenomenon of unaccusativity is an ideal testing ground to examine how syntax and semantics are differentially affected in L2 acquisition and incomplete acquisition. Reduced input (in comparison with L1 input in L2 acquisition and L2 input in language attrition), type of input (written vs, oral, also literacy), and frequency of use, among other cognitive factors, may conspire to promote these incomplete grammatical states when compared with monolingual speakers in these acquisition and loss situations. Intermediate and advanced L2 learners and heritage speakers displayed comparably similar knowledge of the syntax and semantics of unaccusativity, which suggests that at these levels of proficiency the linguistic outcomes of these two situations appear to converge. Yet, important differences between these two populations were revealed at the lowest levels of proficiency tested, where the bilingual heritage speakers displayed a significant linguistic advantage.

Although generative approaches to second language acquisition have often been criticized for not having pedagogical implications, this study shows that linguistic theory as applied to L2 acquisition and adult early bilinguals could become crucial to inform the construction of linguistic instruments for identifying measurable differences and similarities between these different types of bilinguals, and perhaps to devise more subtle diagnostic tools to understand the specific types of linguistic knowledge that heritage speakers have or lack. In this way, practitioners will be in a better position to address the many linguistic and pedagogical needs of heritage speakers and second language learners, especially when they find themselves in the same second language class. 
Acknowledgements

The research presented in this article was conducted under the generous support of the University of Illinois Campus Research Board, for which I am grateful. I want to thank María Isabel Martínez Mira and Justin Sánchez for their invaluable help recruiting participants and conducting all the testing. Different aspects of this work were presented at the First Conference on First Language Attrition held at the Vrije Universiteit Amsterdam, August 22-24 2002, at Carnegie Mellon University, the University of California-San Diego, Michigan State University and the University of Illinois at Chicago. I want to thank the audience in all these different forums as well as Johanne Paradis, José Ignacio Hualde, Mónica Schmid, and two other anonymous Second Language Research reviewers for their invaluable feedback and suggestions. All remaining errors are my own.

\section{References}

Aranovich, R. 2000: Spanish inchoatives and the semantics of split intransitivity. Paper presented at the Annual Meeting of the Linguistic Society of America, Chicago, IL.

Au, T., Knightly, L., Jun, S. and Oh, J. 2002: Overhearing a language during childhood. Psychological Science 13, 238-43.

Babyonishev, M., Ganger, J., Pesetsky, D. and Wexler, K. 2001: The maturation of grammatical principles: evidence from Russian unaccusatives. Linguisitic Inquiry 32, 1-44.

Balcom, P. 1997: Why is this happened? Passive morphology and unaccusativity. Second Language Research 13, 1-9.

Bard, E., Robertson, D. and Sorace, A. 1996: Magnitude estimation of linguistic acceptability. Language 72, 32-68.

Bel, A. 2001: Teoría Lingüistica i adquisició del llenguatge: analisi comparada del trets morfologics en catala i en castella [Linguistic theory and Language acquisition: a comparative analysis of morphological features in Spanish and Catalan]. Barcelona: Institut d'estudis catalans.

Bialystok, E. 2001: Bilingualism in development. Language, literacy and cognition. Cambridge: Cambridge University Press.

Bley-Vroman, R. 1990: The logical problem of foreign language learning. Linguistic Analysis 20, 3-49.

Borer, H. and Wexler, K. 1987: The maturation of syntax. In Roeper T. and Williams, E., editors, Parameter Setting. Dordrecht: Reidel, 123-72. 
Bouba, M., Filiaci, F., Heycock, C., Sorace, A. and Tsimpli, I. 2002: syntactic attrition in Greek and Italian near-native speakers. Paper presented at the First Conference on Language Attrition. August 21-23, Vrijie Universiteit Amsterdam, Amsterdam, The Netherlands.

Bruhn de Garavito, J. 2000: The syntax of Spanish multifunctional clitics and near native competence. Unpublished doctoral dissertation. McGill University, Montreal.

Burzio, L. 1986: Italian syntax: a government and binding approach. Dordrecht: Reidel.

Chomsky, N. 1995: The minimalist program. Cambridge, MA: MIT Press.

Contreras, H. 1978: El orden de las palabras en español [Word order in Spanish]. Madrid: Cátedra.

Cook, V., editor 2003: The effects of the second language on the first. Clevedon: Multilingual Matters.

dc Bot, K. and Clyne, M. 1989: Language reversion revisited. Studies in Second Language Acquisition 11, 17-28.

de Bot, K. and Weltens, B. 1991: Recapitulation, regression and language loss. In Seliger, H. and Vago, R., editors, First language attrition. Cambridge: Cambridge University Press, 31-51.

de Groot, A.M. 1995: Determinants of bilingual lexicosemantic organization. Computer Assisted Language Learning 8, 151-80.

de Groot, A.M. and Kroll, J., editors 1997: Tutorials in bilingualsim. Mahwah, NJ: Lawrence Erlbaum.

de Miguel, E. 1992: El aspecto en la sintaxis del español: perfectividad e imperfectividad [Aspect in Spanish syntax: perfectivity and imperfectivity]. Madrid: Ediciones de la Universidad Autónoma de Madrid.

Demonte, V. 1985: Papeles temáticos y sujetos sintácticos en el sintagma nominal [Thematic roles and syntactic subjects in noun phrases]. Rivista di Grammatica Generativa 9-10, 265-331.

Dorian, N. 1973: Grammatical change in a dying dialect. Language 49, 414-38.

— 1978: The fate of morphological complexity in language death. Language 54, 590-609.

— 1981: Language death. Philadelphia, PA: University of Pennsylvania Press.

Dowty, D. 1991: Thematic proto-roles and argument selection. Language 67, 547-619

Duffield, N. and White, L. 1999: Assessing L2 knowledge of Spanish clitic placement: convergent methodologies. Second Language Research 15, 133-60.

Dussias, P. 2003: Syntactic ambiguity resolution in L2 learners: some effects of bilinguality on L1 and L2 processing strategies. Studies in Second Language Acquisition 25, 529-57. 
Elías-Olivares, L., editor 1983: Spanish in the United States: beyond the southwest. Washington, DC: National Center for Bilingual Education.

Gal, S. 1979: Language shift: social determinants of linguistic change in bilingual Austria. New York: Academic Press.

Grosjean, F. 1994: Individual bilingualism. The encyclopedia of language and linguistics. Oxford: Pergamon, 1656-60.

Grosjean, F. and Soares, C. 1986: Processing mixed languages: some preliminary findings. In Vaid, J., editor, Language processing in bilinguals: psycholinguistic and neurological perspectives. Hillsdale, NJ: Lawrence Erlbaum, 145-79.

Gürel, A. 2002: Linguistic characteristics of second language acquisition and first language attrition: Turkish overt vs. null pronouns. Unpublished $\mathrm{PhD}$ dissertation, McGill University.

Hawkins, R. 2001: Second language syntax. Malden, NJ: Blackwell.

Herschensohn, J. 2000: The second time around: minimalism and L2 acquisition. Amsterdam: John Benjamins.

Hirkawa, M. 1995: L2 acquisition of English unaccusative constructions. In MacLaughlin, D. and McEwen, S., editors, Proceedings of the 19th Boston University conference on language development. Sommerville, MA: Cascadilla Press, 291-302.

- 2000: Unaccusativity in second language Japanese and English. Unpublished doctoral dissertation. McGill University, Montreal.

- 2001: L2 acquisition of Japanese unaccusative verbs. Studies in Second Language Acquisition 23, 221-46.

Hyltenstam, K. 1992: Non-native features of near-native speakers: on ultimate attainment of childhood L2 learners. In Harris, R., editor, Cognitive processing in bilinguals, Amsterdam: Elsevier, 351-68.

Hyltenstam, K. and Abrahamsson, N. 2003: Maturational constraints in SLA. In Doughty, C. and Long, M., editors, The handbook of second language acquisition, Oxford: Blackwell, 539-88.

Hyltenstam, K. and Viberg, A., editors 1993: Progression and regression in language: sociocultural, neuropsychological and linguistic perspectives. New York: Academic Press.

Inagaki, S. 2002: Transfer and learnability in second language argument structure: motion verbs with locational/directional PPs in L2 English and Japanese. Unpublished doctoral dissertation, McGill University, Montreal.

Jakobson, R. 1941: Kindersprache, aphasie, and allgemeine Lautgezetze [Child language, aphasia and general phonology]. Uppsala: Almqvist and Wiksell. (Also in Jakobson, R., Selected writings, 1, phonological studies. Den Haag: Mouton. 1962.)

Johnson, J. and Newport, E. 1991: Critical period effects on universal properties of language: the status of subjacency in the acquisition of a second language. Cognition 39, 215-58. 
Jordens, P. 2002: Learner varieties in the study of attrition. Plenary talk, First Conference on First Language Attrition. Vrije Universiteit Amsterdam, August 22-24.

Jordens, P., De Bot, K. and Trapman, H. 1989: Linguistic aspects of regression in German case marking. Studies in Second Language Acquisition 11, 179-204

Juffs, A. 1998: The acquisition of semantics-syntax correspondences and verb frequencies in ESL materials. Language Teaching Research 2, 93-123.

Kageyama, T. 1996: Doushi-imiron [Verb Semantics]. Tokyo: Kuroshio.

Kellerman, E. 1978: Giving learners a break: native language intuitions as a source of predictions about transferability. Working Papers on Bilingualism 15, 59-48.

Kohnert, K., Bates, E. and Hernández, A. 1999: Balancing bilinguals: lexical-semantic production and cognitive processing in children learning Spanish and English. Journal of Speech, Language and Hearing Research 42, 1400-13.

Kohnert, K. and Bates, E. 2002: Balancing bilinguals II: lexical comprehension and cognitive processing in children learning Spanish and English. Journal of Speech, Language and Hearing Research 45, 347-59.

Kroll, J. and Sunderman, G. 2003: Cognitive processes in second language learners and bilinguals: the development of lexical and conceptual representations. In Doughty, C. and Long, M., editors, The handbook of second language acquisition. Oxford: Blackwell, 104-29.

Köpke, B. 2002: Activation thresholds and non-pathological attrition. In Fabbro, F., editor, Advances in the neurolinguistics of bilingualism. Essays in honor of Michael Paradis. Udine: Forum, 119-42.

Legendre, G. 1989: Unaccusativity in French. Lingua 79, 95-164.

Levin, B. and Rappaport Hovav, M. 1995: Unaccusativity at the syntax semantics interface. Cambridge, MA: MIT Press.

— 2002: An event structure account of English resultatives. Language 77, 766-97.

Lipski, J. 1993: Creoloid phenomena in the Spanish of transitional bilinguals. In Roca, A. and Lipski, J., editors, Spanish in the United States. Berlin: Mouton, 155-73.

Lynch, A. 1999: The subjunctive in Miami Cuban Spanish: bilingualism, contact, and language variability. Unpublished doctoral dissertation, University of Minnesota, Minneapolis, MN.

Major, R. 1992: Losing English as a first language. The Modern Language Journal 76, 190-208.

Meisel, J. 1997: The acquisition of the syntax of negation in French and German: contrasting first and second language development. Second Language Research 13, 227-63. 
- 2001: The simultaneous acquisition of two first languages: early differentiation and subsequent development of grammars. In Cenoz, J. and Genesee, F., editors, Trends in Bilingual Acquisition. Amsterdam: John Benjamins, 11-42.

Montrul, S. 2002: Incomplete acquisition and attrition of Spanish tense/aspect distinctions in adult bilinguals. Bilingualism: Language and Cognition 5, 39-68.

— 2004a: Subject and object expression in Spanish heritage speakers: a case of morpho-syntactic convergence. Bilingualism: Language and Cognition 7, 125-42. Special issue on convergence, edited by Jacqueline Toribio.

— 2004b: Convergent outcomes in second language acquisition and first language loss. In Köpke, B. and Schmid, M., editors, First Language Attrition. Amsterdam: John Benjamins, 259-80.

Montrul, S. and Slabakova, R. 2002: Acquiring morphosyntactic and semantic properties of aspectual tenses in L2 Spanish. In Pérez-Léroux, A-T. and Liceras, J., editors, The acquisition of Spanish morphosyntax: the L1/L2 connection. Dordrecht: Kluwer, 131-49.

— 2003: Competence similarities between native and near-native speakers: an investigation of the preterite/imperfect contrast in Spanish. Studies in Second Language Acquisition 25, 351-98.

Naigles, L. 2002: Form is easy, meaning is hard: resolving a paradox in early child language. Cognition 86, 157-99.

Nicol, J., editor 2001: One mind, two languages. Bilingual language processing. Malden, MA: Blackwell.

Ocampo, F. 1990: El subjuntivo en tres generaciones de hablantes bilingües [The subjunctive in three generations of bilingual speakers]. In Bergen, J., editor, Spanish in the United States: sociolinguistic issues. Washington, DC: Georgetown University Press, 34-48.

Oshita, H. 2001: The unaccusative trap hypothesis in second language acquisition. Studies in Second Language Acquisition 23, 279-304.

Pan, B. and Berko Gleason, J. 1986: The study of language loss: models and hypotheses for an emerging discipline. Applied Psycholinguistics 7, 193-206.

Pavlenko, A. 2000: L2 influence on L1 in late bilingualism. Issues in Applied Linguistics 11, 175-205.

Platzack, C. 1996: The initial hypothesis of syntax: a minimalist perspective on language acquisition and attrition. In Clahsen, H., editor, Generative perspectives on language acquisition. Amsterdam: Benjamins, 369-414.

Polinsky, M. 1997: American Russian: language loss meets language acquisition. Proceedings of the annual workshop on formal approaches to Slavic linguistics. The Cornell Meeting 1995. Ann Arbor, MA: Michigan Slavic Publications, 370-406. 
- 2000: A composite linguistic profile of a speaker of Russian in the US. In Kagan, O. and Rifkin, B., editors, The learning and teaching of Slavic languages and cultures. Bloomington, IN: Slavica, 437-65.

in press: Heritage language narratives. In Kagan, O. and Brinbton, D., editors, Heritage languages: a new field emerging. Hillsdale, NJ: Erlbaum.

Perlmutter, D. 1978: Impersonal passives and the unaccusative hypothesis. Proceedings of the fourth annual meeting of the Berkeley-linguistic society. Berkeley, CA. Berkeley Linguistic Society, University of California, 157-89.

Rappaport Hovav, M. and Levin, B. 1998: Building verb meaning. In Butt, M. and Geuder, W., editors, The projection of arguments. Lexical and compositional factors. Stanford, CA: CSLI publications, 97-134.

Ritter, E. and Rosen, S. 1998: Delimiting events in syntax. In Butt, M. and Geuder, W., editors, The projection of arguments. Lexical and compositional factors. Stanford, CA: CSLI publications, 135-64.

Rosen, C. 1984: The interface between semantic roles and initial grammatical relations. In Perlmutter, D. and Rosen, C., editors, Studies in Relational Grammer 2. Chicago, IL: University of Chicago Press, 38-77.

Schlyter, S. 1993: The weaker language in bilingual Swedish-French children. In Hyltenstam, K. and Viberg, A., editors, Progression and regression in language, Cambridge: Cambridge University Press, 289-308.

Schmid, M. 2002: First language attrition, use and maintenance: the case of German Jews in anglophone countries. Amsterdam: John Benjamins.

Seliger, H. 1991: Language attrition, reduced redundancy and creativity. In Seliger, H. and Vago, R., editors, First language attrition. Cambridge: Cambridge University Press, 227-40.

- 1996: Primary language attrition in the context of bilingualism. In Ritchie, W. and Bhatia, T., editors, Handbook of second language acquisition. New York: Academic Press, 605-25.

Seliger, H. and Vago, R., editors 1991: First language attrition. Cambridge: Cambridge University Press.

Silva-Corvalán, C. 1994: Language contact and change. Oxford: Oxford University Press.

— 2003: Linguistic consequences of reduced input in bilingual first language acquisition. In Montrul, S. and Ordóñez, F., editors, Linguistic theory and language development in Hispanic languages: papers from the Fifth Hispanic Linguistics Symposium and the Fourth Conference on the Acquisition of Spanish and Portuguese. Sommerville, MA: Cascadilla Press, 375-97.

Sharwood Smith, M. April 2001: The unsteady state: an SLA perspective on first language attrition. Paper presented at the Third International Symposium on Bilingualism, Bristol, available at: http://www.hw.ac.uk/ langWWW/mss/loss_bestanden/frame.htm (October 2004). 
Sharwood Smith, M. and van Buren, P. 1991: First language attrition and the parameter setting model. In Seliger, H. and Vago, R., editors, First language attrition. Cambridge: Cambridge University Press, 17-30.

Snyder, W., Hyams, N. and Crisma, P. 1995: Romance auxiliary selection with reflexive clitics: evidence for early knowledge of unaccusativity. In E., Clark, editor, The proceedings of the twenty-sixth annual child language research forum. Stanford, CA: CSLI Publication, 127-36.

Sorace, A. 1993a: Incomplete vs. divergent representations of unaccusativity in native and non-native Italian grammars of Italian. Second Language Research 9, 22-47.

- 1993b: Unaccusativity and auxiliary choice in non-native grammars of Italian and French: asymmetries and predictable indeterminacy. Journal of French Language Studies 3, 71-93.

- 1995: Acquiring linking rules and argument structures in a second language: The unaccusative/unergative distinction. In Eubank, L., Selinker, L. and Sharwood Smith, M., editors, The current state of interlanguage. Amsterdam: John Benjamins, 153-75.

_ 1999: Initial states, end-states and residual optionality in L2 acquisition. Proceedings of the 23th Boston University conference on language development. Sommerville, MA: Cascadilla Press, 666-74.

— 2000a: Differential effects of attrition in the L1 syntax of near-native L2 speakers. Proceedings of the 24th Boston University conference on language development. Sommerville, MA: Cascadilla Press, 719-25.

- 2000b: Gradients in auxiliary selection with intransitive verbs. Language 76, 859-90.

Sorace, A. and Shomura, Y. 2001: Lexical constraints on the acquisition of split intransitivity: evidence from L2 Japanese. Studies in Second Language Acquisition 23, 247-78.

Suñer, M. 1982: Syntax and semantics of presentational sentences types. Washington, DC: Georgetown University Press.

Toribio, A. 2001: On Spanish language decline. Proceedings of the 25th Boston University conference on language development. Sommerville, MA: Cascadilla Press, 768-79.

Torrego, E. 1989: Unergative-unaccusative alternations in Spanish. MIT Working Papers in Linguistics 10, 253-69.

Tsimpli, I. 2001: LF-Interpretability and language development: a study of verbal and nominal features in Greek normally developing and SLI children. Brain and Language 77, 432-48.

Vihman, M. and McLaughlin, B. 1982: Bilingualism and second language acquisition in preschool children. In Brainerd, C. and Pressley, M., editors, Verbal processes in children. Berlin: Springer, 35-58.

Valdés, G. 2000: Spanish for native speakers: AATSP professional development series handbook for teachers K-16. Volume 1. New York: Harcourt College Publishers. 
van Hout, A. 1996: Event semantics and verb frame alternations: a case study of Dutch and its acquisition. Tilburg: Tilburg Dissertations in Language Studies.

van Hout, A., Randall, J. and Weissenborn, J. 1992: Acquiring the unaccusative/unergative distinction. In Verrips, M. and Wijnen, F. editors, The acquisition of Dutch. Amsterdam series in child language development 1,79-120. Amsterdam: University of Amsterdam.

Van Valin, R. 1990: Semantic parameters of split intransitivity. Language 66, 221-60.

Vendler, Z. 1967: Verbs and Times. Philosophical Review 56, 143-60.

White, L. 1991: Argument structure in second language acquisition. French Language Studies 1, 189-207.

- 2003: Second language acquisition and universal grammer. Cambridge: Cambridge University Press.

Yip, V. 1995: Interlanguage and learnability. Philadelphia, PA: John Benjamins.

Yuan, B. 1999: Acquiring the unaccusative/unergative distinction in a second language: evidence from English-speaking learners of Chinese. Linguistics 37, 275-96.

Zaenen, A. 1993: Unaccusativity in Dutch: integrating syntax and lexical semantics. In Pustejovsky, J., editor, Semantics and the lexicon. Dordrecht: Kluwer.

Zentella, A.C. 1997: Growing up bilingual. Puerto Rican children in New York. Malden, MA: Blackwell.

Zobl, H. 1989: Canonical typological structures and ergativity in English L2 acquisition. In Gass, S. and Schachter, J., editor, Linguistic perspectives on second language acquisition. Cambridge: Cambridge University Press, 203-21. 